\title{
An Alternative Approach to the Conservation and Fruition of the Phlegraean Fields Archaeological Landscape
}

\author{
By Marco Russo
}

The Phlegraean Fields in Italy presents an abundance of underwater archaeological sites. The area was the favourite location for roman citizens that built a city in this territory. Today there are only parts of walls and columns, all statues and decoration were destroyed or lost due pillages of 80's. Now citizens try to restore the antique bond with the sea and with the archaeological heritage. This paper discusses the possible urban development of this abandoned cultural heritage, a landscape vision capable to connect various sites along shoreline. A large-scale project where economic and social resources focused on reuse of these underwater and coastal assets. New low-tech structures designed to protect roman ruins, not a utopian vision but a real solution for this territory that erased his ancient relationship with the sea. A project along the coastline of Phlegraean Fields that generate connections, restoring the ancient bond with the sea.

Keywords: archaeology, landscape planning, underwater archaeology, Phlegraean fields, urban acupuncture

\section{Introduction}

The proposed urban vision is not a finished project but an idea for the restoration of the underwater and the coastal archaeological sites of the Phlegraean Fields, a preliminary idea to develop with workshops or architectural competitions for the six areas identified in the paper. The area of the Nymphaeum of Claudio and Pisoni's villa will be the theme of the architecture and urban design lab for the students of the fourth year of the architecture course at Department of Architecture and Industrial Design "Luigi Vanvitelli", where the author works with the Prof. Arch. Efisio Pitzalis. The topic of the paper is part of the $\mathrm{PhD}$ thesis of the author focused on the museumification and valorisation of the underwater and coastal archaeological sites. The author works on real scenario, real project for real sites. These archaeological sites are not far from the coast; their involvement in an urban transformation is possible and necessary. The paper tries to identify a possible urban vision focusing on the reconnection of coast spaces and inner areas of the territory. The scenario of the Phlegraean Fields is not a random choice. There is a constant presence of underwater and coastal sites along the contemporary shoreline, most of them from I century BC, during the roman

*PhD Student, Department of Architecture and Industrial Design "Luigi Vanvitelli", Second University of Naples, Italy. 
period. In the imperial roman age, the area was full of constructions, but only the majestic buildings survived during the centuries.

An urban vision that is not based only on a traditional masterplan. One large-scale project through an architect represents their idea, a general plan that will follow further levels of design and needs several years to end. The aim is to represent this urban transformation with a masterplan as a large-scale strategy, not as a stand-alone project, with small-scale projects that will be the real local actions (Urhahn 2011). This design process is a typical strategy of the urban acupuncture.

Urban Acupuncture is the combination of small scaled, strategically placed, catalytic interventions that stimulate urbanism and result in the maximum effect through the minimum investment (Solà-Morales 1999). There is not a precise set of rules for the application of the theory, just principle ideas. One of the most interesting element of these processes are low-cost techniques, very easy, cheap and fast to build. Start-up or citizen's organizations that usually work with low budget, should build part of these structures. Many projects are for poor areas, as the slums of Medellín in Colombia. There are few examples in other countries for these empty urban spaces like the projects Time to Change from the group Collectif Etc in Saint-Etienne or the EcoInterstice from the collective AAA (Atelier d'architecture Autogérée) in the area of St. Blaise, east of Paris (Russo 2014). One of the most popular examples is the Taipei neighbourhood Treasure Hill, illustrated in many articles by Finnish architect Marco Casagrande. These urban transformations are designed not only by architects but with the assistance of the designers. The active presence of the citizens is necessary to create identity too. Within interventions on the smallest scale, it is good to involve the residents in this transformation process; as the users of an area, they are in some cases not only stakeholders but also experts.

The presence of this kind of cultural heritage should represent a key element to improve the quality of these spaces, allowing people to visit easily the archaeological sites and to create a physical connection from the shoreline to the inner zones destroyed during the centuries. Not a simple connection as a walk-path or a bridge but an urban infrastructure with dynamic functions inside, that can change depending on citizens needs (Carmona et al. 2010).

Cities are rapidly growing and their problems are growing with them. Nowadays planners do not have any time to plan cities constantly changing. This alternative seeks a perfect allocation of urban projects with high impact, whose evolution goes at the same speed of the evolution of communities to restore archaeological sites with low-tech / low-cost solutions. The aim of the paper is to suggest low budget solutions and to improve the underwater tourism. A good example for the valorisation of underwater and coastal cultural heritage, with low budget solutions is the Teti project, developed by a group of $\mathrm{PhD}$ researchers from the Polytechnic of Milan with Prof. Emma Angelini as principal academic tutor, an easy solution for underwater archaeological sites through the realization of underwater lighting installation along the ruins. The 
six archaeological sites illustrated in this paper are at 4/6 m deep and can be visited only by divers or snorkel.

The main idea is not to build new underwater museums. It is a solution very expensive and difficult because there are too many archaeological sites. If we considered a plan with the construction of six new museums, we should have a multi-million budget. In accordance with the website of UNESCO organization, the Baiheliang Underwater Museum of Fuling or the Maritime Silk Road Museum (Nanhain.1 Museum) in the region of Guangdong, both in China, are two of the less expensive buildings with the approximately cost of 25.000.000 of U.S. dollars. If this budget was increased of six times as the sites, the plan should be of 150.000 .000 of U.S. dollars. This kind of solution is possible only with strong investments. The project of the French architect Jacques Rougerie for Alexandria, with the final cost of 100.000.000 of U.S. dollars, is another example of these expensive solutions for the coastal and underwater archaeological sites.

The urban vision shows six specific underwater and coastal archaeological sites. These sites have a strategic position in the landscape because they are in the last empty areas in the territory, a great resource for citizens and private investors. It is possible to achieve public functions with a great touristic interest that are not existing today or where they exist are not in a correct dimension. This urban vision is possible only through a thigh collaboration between public and private investors. Municipalities have not sufficiently founds for this transformation.

It will be important organize the construction sites as a process by phases. In this way, people will continue to use part of the site with public ephemeral functions. They will not be empty areas for years, waiting for a development project. This process by phases is a contemporary urban vision very used by Spanish urban planners. First of all, they start using the area with temporary activities during the period between the approval of the project and its construction, in this way citizens have an immediate comfort and they have not wait for five or ten years the construction of a square or a public building. The author presents a critic to the new project of the waterfront of Pozzuoli designed by Peter Eisenmann. Note that the criticism is not at the project but at its fulfilment. The idea is to change the area in $15 / 20$ years, but in this scenario people cannot use this public functions for years. People need them now. Time is a way to evaluate an urban transformation. In the next chapters the author will illustrate the areas of this proposal and the modality to build it. The paper shows these urban processes by sketches of the author and how and why is important the active collaboration of local people, a concept well expressed by studies on urban acupuncture. People have a marginal role in traditional urban transformations. The Phlegraean Fields are the best study case to design this scenario. People are already active with no profit organizations that offer free visits and courses on underwater archaeology. Protect our underwater cultural heritage, a concept that comes from the UNESCO Convention on Underwater Cultural Heritage, is the key. Protection of this heritage in danger, the improvement of the accessibility to sites and the 
conservation in situ are the main options (Maarleveld et al. 2013). The urban proposal in the paper focused on alternative solution for valorisation of cultural heritage, contemporary solutions with a low budget. Solutions capable to connect empty areas to the shoreline, rebuilding this historic connection. With this paper, the author wants to show the main strategy that tends to resolve unpleasant situations like the picture below. The figure 1 comes from the website of the MiBACT. It is the roman theatre of Miseno with its spectacular lights. In the figure 2 , there is the real situation during a free visit organized by a local association with lights out. This two figures show the real condition of the archaeological sites in this territory and their bad management.

Figure 1. Image from the Official Website of the MiBACT

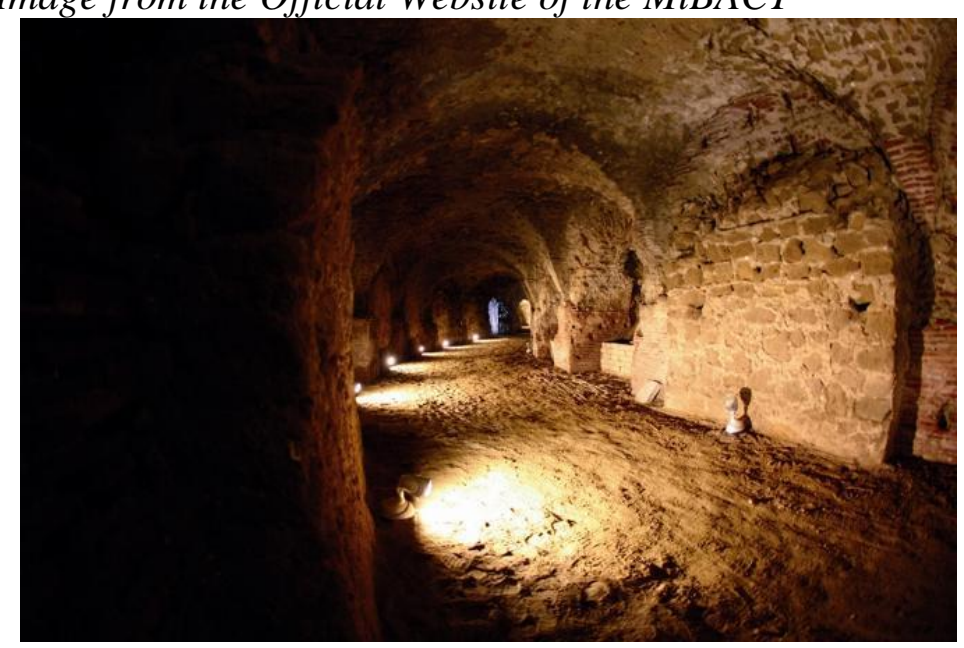

Source: MiBACT 2010

Figure 2. Real Situation during a Visit in the Roman Theatre of Miseno, 07-03201512.47

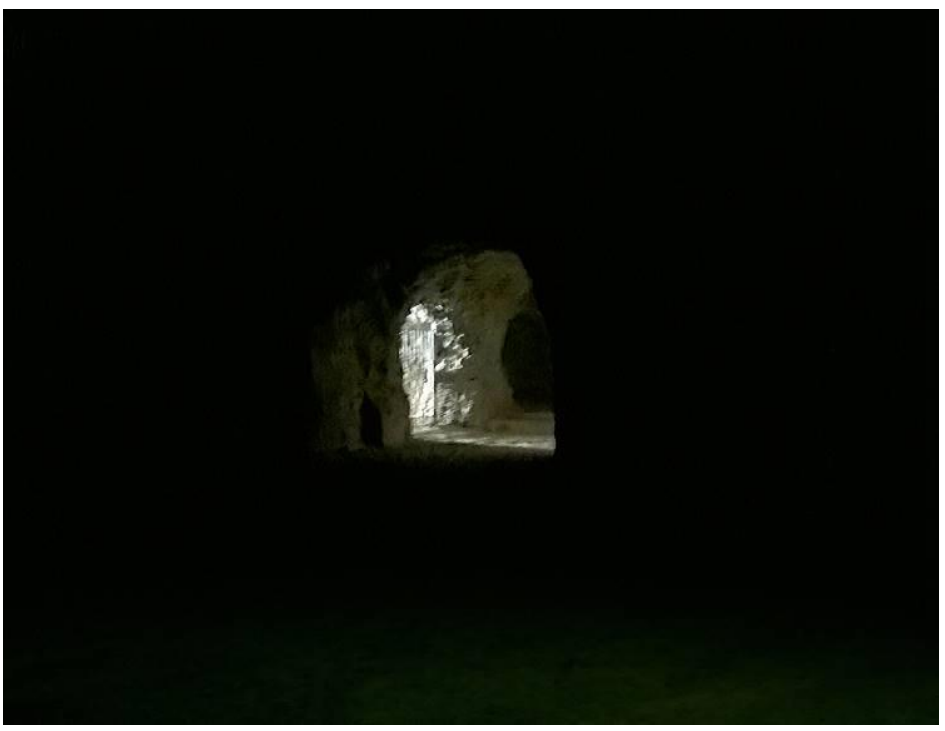

Source: M. Russo 


\section{The Phlegraean Fields}

This area has raised a multitude of suggestions over the millennia. This territory was generated by an intense volcanic activity. This geological phenomenon is still alive, in the centuries the cradle for many myths related to idea of the life after death. A region characterized by craters, fumaroles, forests, ancient submerged heritage, archaeological remains and lakes. Well described during the period of the Grand Tour, where scholars from all over Europe portrayed the remains of Greek, Roman and Sunni civilization with smoking chimneys generated by volcanoes in the background (Fino 2001).

Figure 3. Plan of the Gulf of Pozzuoli by F. De La Vega, 1782

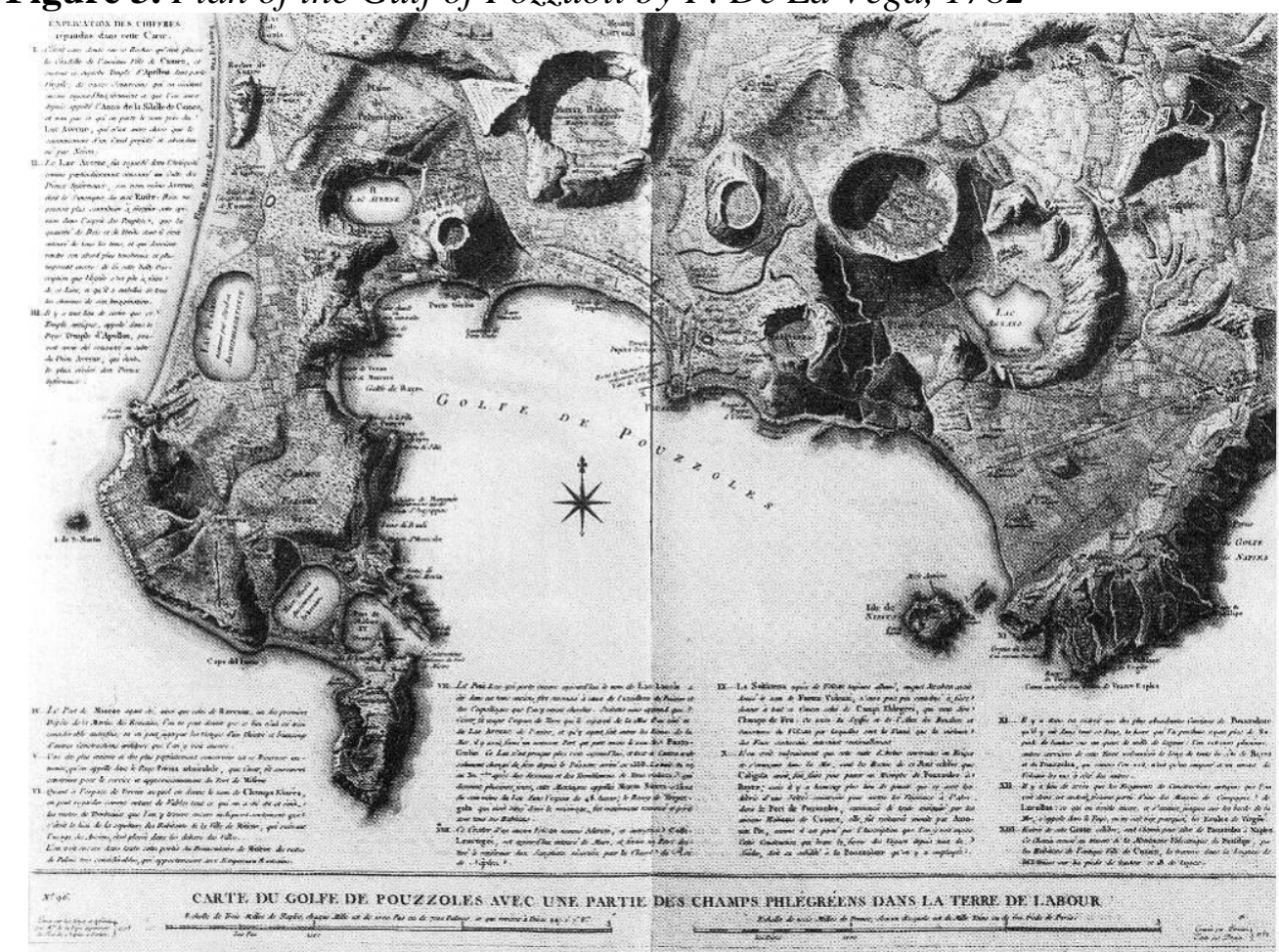

Source: University Library of Berne

The Roman period was certainly the one that left the most important mark in the territory. On the coast between Pozzuoli and Miseno, we find several port facilities that welcomed the main Roman fleet in the West. Later the attention of the Romans moves to natural hydrothermal sources in Baia, with the consequent construction of an unknown number of seaside villas. Baia in ancient Rome was the place where wealthy romans were staying and spent their free time at thermal bath; there were several structures due the volcanic springs. With construction of the port of Ostia, the new port of ancient Rome began a social and economic crisis accentuate by bradyseism. The area of the Phlegraean Fields is one of the areas with greater presence of archaeological ruins and natural resources, buildings constructed along the coast ended 
underwater; today the coastline is retreated to $40 \mathrm{~m}$ compared with the Roman shoreline.

Underwater Roman buildings have been rediscover only in the mid 900's in Phlegraean Fields. Landscape painters put the focus on small parts of the ruins emerges from the sea.

The oldest map of the area represented in the glass flasks from Odemira, Prague and Pilkington, on the glass surface there was the topographic image of Puteoli and Baiae with the main monuments (Di Fraia et al. 1986). After the renewed interest at the beginning of the '900 resumes since 1959 (Scognamiglio 2006) the relief program by Maiuri and Lamboglia (Maiuri 1983). Based on surveys and direct observations of the archaeologists have played a submerged archaeological map of the bay including the most famous areas as the site of the Baianus lacus, the nymph of Claudio and the less famous site as the roman fishpond under the Aragonese castle of Baia.

A detailed list of the most important archaeological sites will be described later in the paper.

Figure 4. Plan of the Underwater Archaeological Sites in Baia drawn by Eduardo Scognamiglio (Scognamiglio 1998): a_ nymphaeum of Emperor Claudio; b_ thermal bath; c_Pisoni's villa; d_fishpond and breakwaters, e_rests of the roman thermal bath with and villa, f_entrance canal to the Baianus Lacus, g_roman ruin, h_Stagnum Neronis.

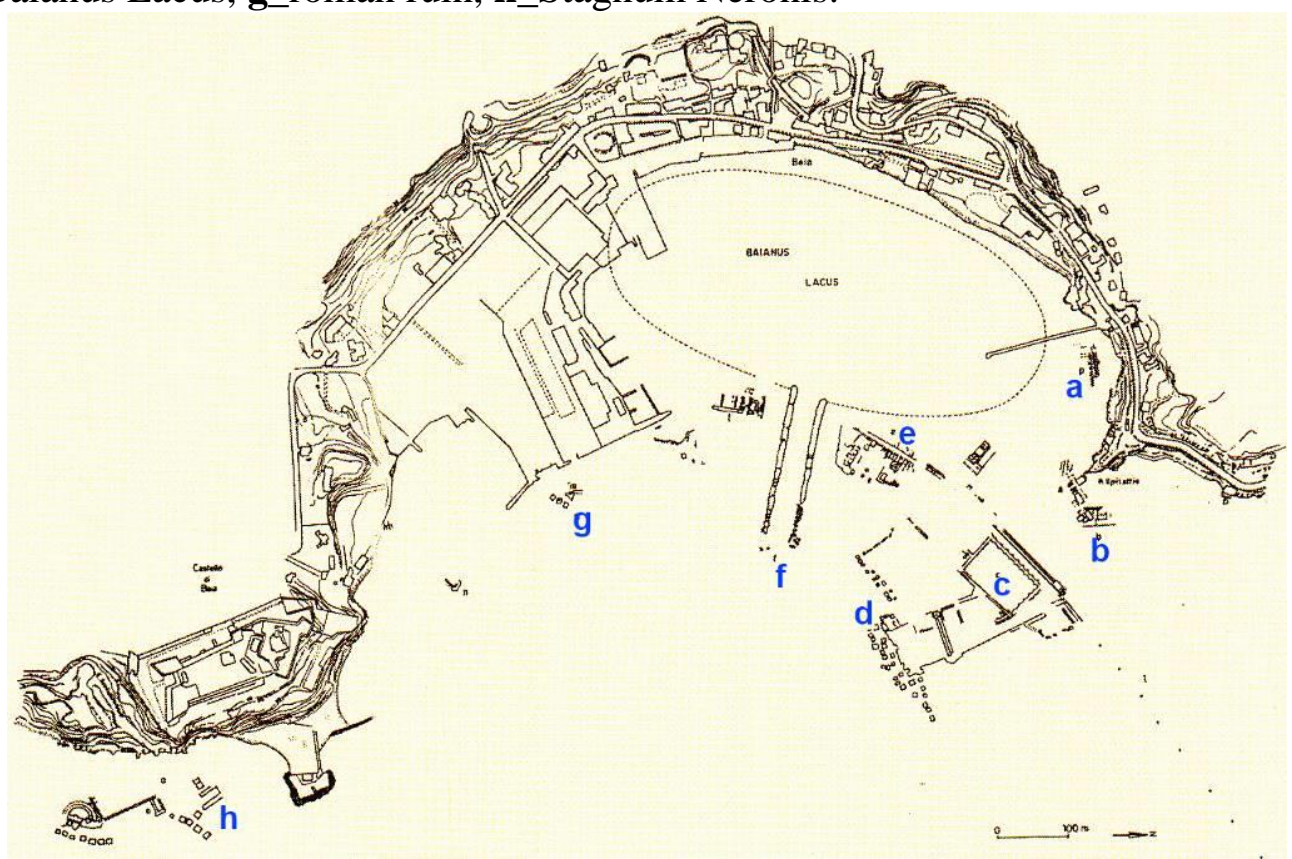

Source: E. Scognamiglio

The underwater cultural assets are undergoing a special safeguard by UNESCO. Otherwise, only with the UNESCO convention on the Protection of the Underwater Cultural Heritage (2001) has come to an official document approved by more countries (Dromgoole 2003). 
Today due modern technologies, it is possible to make immersion at a derisory price, this factor caused decay and bare of underwater sites. Involving the loss of priceless assets, composed of statues, amphorae and movable decorations.

The convention suggests a series of actions to limit or spare damages wood furniture, underwater structures and objects that must be in particular hygrometric conditions. The UNESCO document recommends in situ preservation, describing it as the best way for the conservation of underwater cultural heritage. Clearly, there is not common strategies for all sites, each site has its own history and its problems, and it is the basic concept of the restoration works.

There are many solutions present on the website of the UNESCO for underwater cultural heritage represented by building or other technics. The proposal in this paper reject solutions as underwater structures or in situ solutions as the metal cage in Croatia covering a shipwreck off Pag. The aim of the article is to visit this amazing heritage underwater. A solution similar at the proposal of TETI project developed by $\mathrm{PhD}$ researchers of the Polytechnic of Milan. Project based on "underwater museum" improving the divers experience with light paths and info panels, already used in underwater visits in the Phlegraean Fields. This solution guarantees constant visits at archaeological sites and would be an easy way to monitoring the sites as suggests by UNESCO Convention on Underwater Cultural Heritage of 2001. The coast could be converted in a public space with the addition of artificial shoreline in the six main archaeological sites, a simple solution with minimal intervention would facilitate protection operations of underwater and coastal sites, while providing public seaside, missing in Baia and Miseno. 
Vol. 2, No. 1 Russo: An Alternative Approach to the Conservation and Fruition...

Figure 5. Plan of the Archaeological Sites in Baia and Miseno

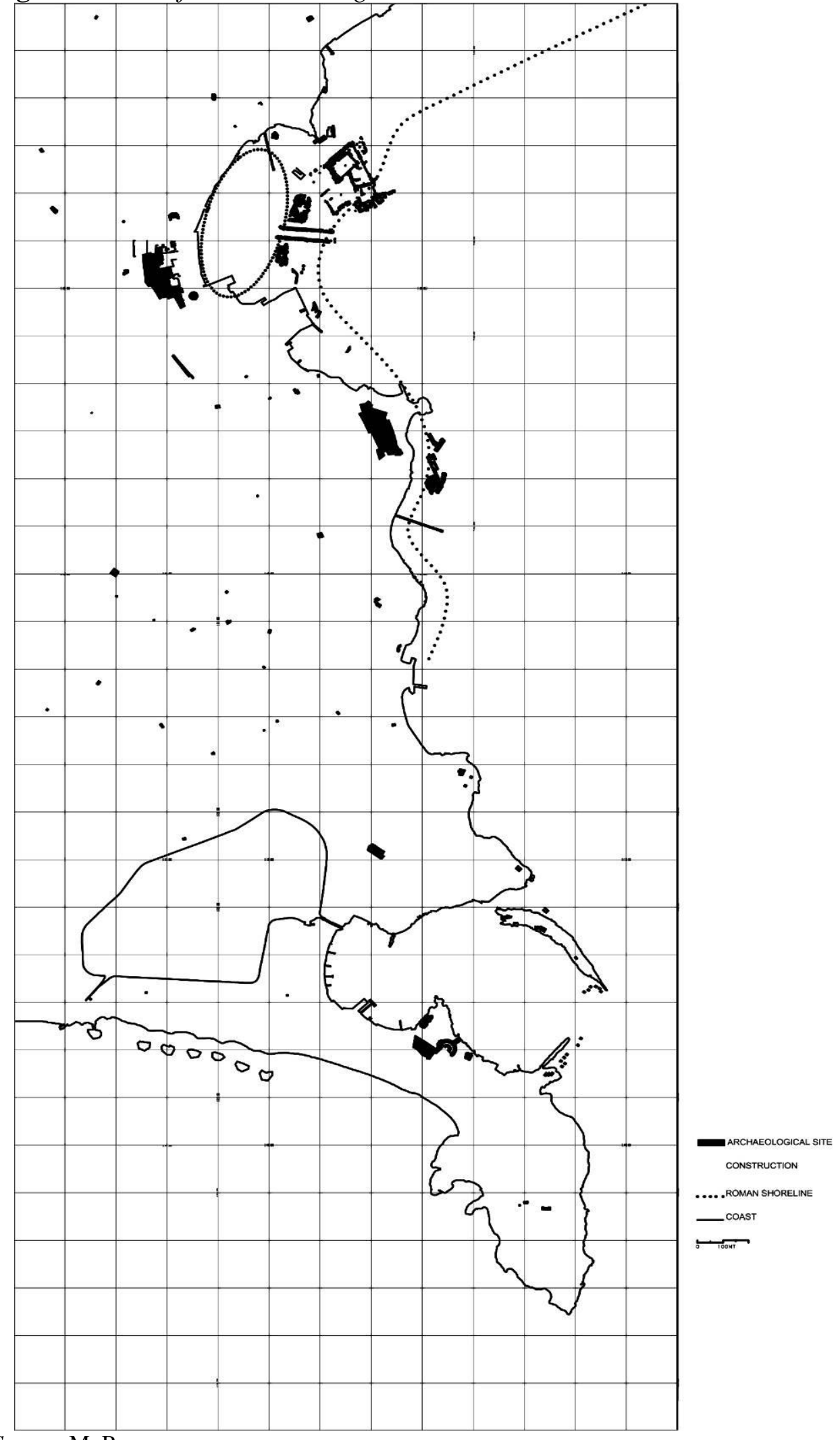

Source: M. Russo 


\section{Timeline}

The urban vision proposed in this paper tends to eliminate the "waiting period" during the realization of the construction site; temporary functions, events and ephemeral architectures should give a new image to areas. These activities can be realised with a minimum use of economic resources and built by citizens in a short time. Planners have to opt for gradual and adaptable solutions, which maintain a spatial and economic vitality. Urban transformation projects have a lapse of time between 10 and 20 years. The project presented for the waterfront of Pozzuoli involves a transformation into a medium / long time (20 years). This policy shows all its downsides. Since the adoption of P.U.A., from 2009 to 2015, not even a construction site started. The Ex Sofer area is still in a degradation state, after six years. Social bother increases due people forced to live in an area of great urban decay. The timeline of the project contrasts with the dynamics of traditional plans and specifically with the proposed masterplan for Pozzuoli. For sure it is not possible to explain the entire plan because there are too many functions in an area of $270.000 \mathrm{~m}^{2}$. The total investment is 180 million of euro for development of the Ex Sofer, which is the key-project of the masterplan. This project is highlighted in the figure 6 with the black rectangle. The aim of the redevelopment project of the Ex SOFER is the realization of a Multi-purpose Centre for tourism, business and leisure and a site equipped for the development of the arts and professions.

Designers allocate a huge surface to parks and public spaces, the $75 \%$ of the area, $130.000 \mathrm{~m}^{2}$ totally dedicated to green, pedestrians and bicycles. The building will have a low impact on the landscape because will cover only the $25 \%$ of the entire surface. This project will have a strong impact on citizens but it is still in stand-by. The municipality is waiting for funds to build these functions and reclamation of the soil. Today a construction sites is not even started, the changing must wait with bad consequences on local economy and people.

Figure 6. New Waterfront of Pozzuoli, Masterplan by Peter Eisenman, 2009

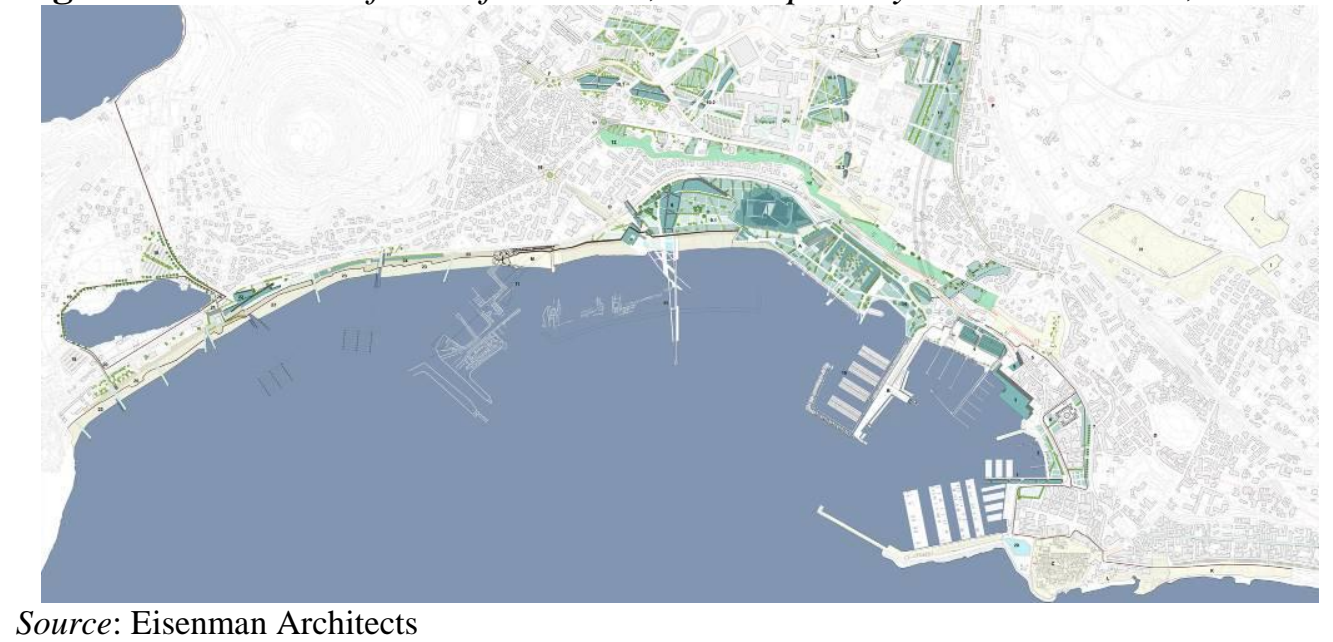




\section{Bad Management of the Territory}

Deeply affected by the economic crisis, the territory of Phlegraean Fields failed to invest their scarce resources for the revitalization of the area. The most active city is Pozzuoli, with the largest territory and resources while the southern areas of Pozzuoli, Baia, Bacoli and Monte di Procida, are territories with a summer tourism economy. Resources and efforts to promote cultural tourism is necessary. One of the main monument of the area, the Piscina Mirabilis, it is always closed. Museums visitors are dramatically low.

Furthermore, tourism generated on submerged heritage routes with private itineraries is high, organized by non-profit associations not included in the "official" circuits. Volunteers organize many visits at archaeological remains. The economic crisis is sharpening by bad land management. The Phlegraean Fields had an historical connection to the sea. The destruction of this link has led to an impoverishment of the urban fabric, built in many cases above the archaeological remains, leading to its partial destruction. It is famous the case of the roman theatre of Miseno, engulfed in a series of private buildings. Along the coast, we find a series of large and small tourist ports. So, if the cultural circuits do not work or do not exist, why tourists should visit these places? The function of the marina has a number of problems clearly visible in the areas analysed. In the front of the moorings, there is a parking, as in port of Baia, an area that is exposed on Naples with very suggestive points of view, just a few meters from coastal and submerged assets.

Figure 7. Photo of the Touristic Port of Baia, 12-04-2015

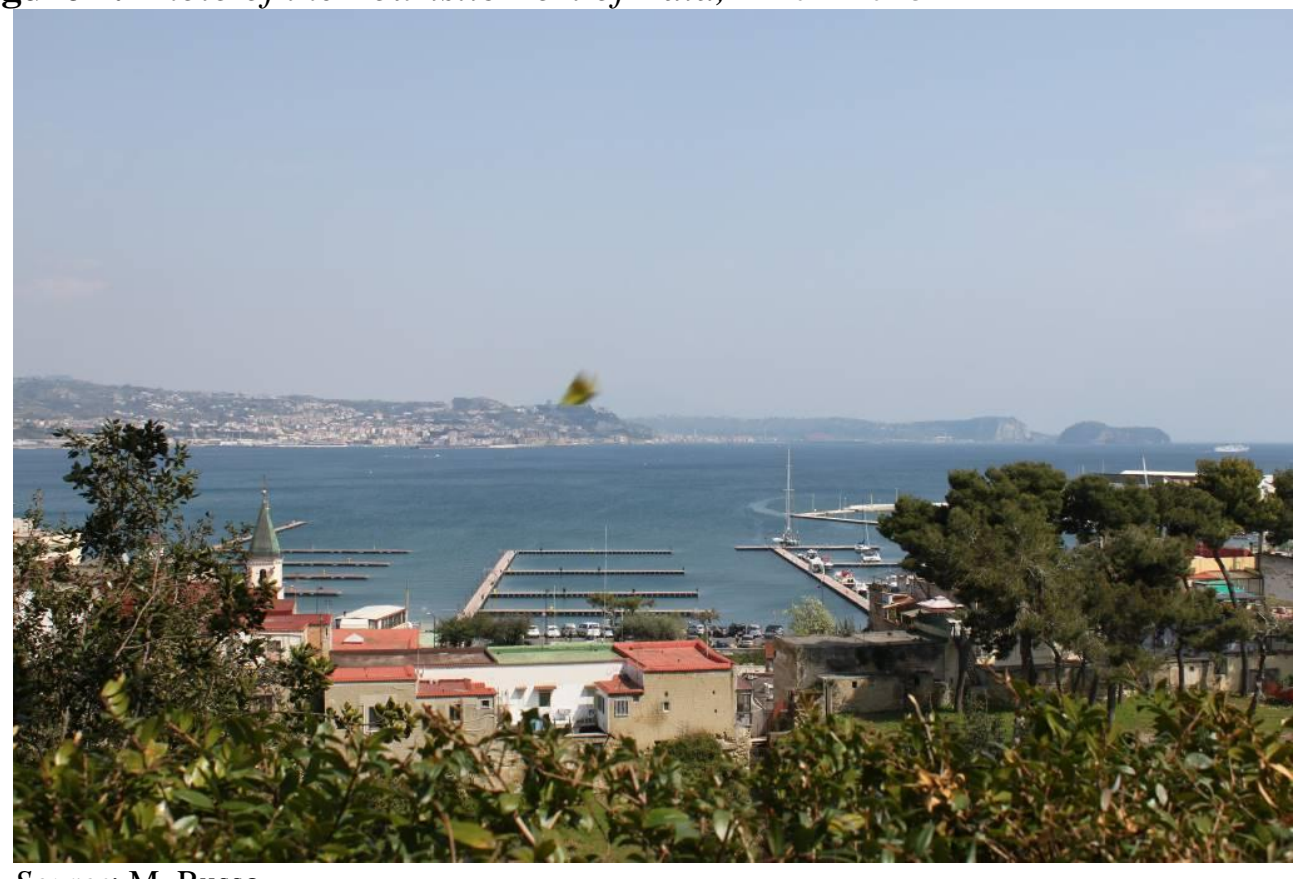

Source: M. Russo

This article examines the possibility to redevelop this area starting from the archaeological coastal and underwater heritage positioned along the coast. In Roman times, the many seaside villas and military ports, born in different 
centuries along the Phlegraean coast, creating connection between land and sea. The alteration of these bonds led to the breakdown of a balance consolidated for centuries. Furthermore, these "connections" has been misinterpreted. It is dotted with touristic ports and shipyards. Functions that have a great social impact, used only in summer because of precarious employment, given the niche sector fell in a deeply crisis.

In this scenario, it feels a deep unease visiting the archaeological monuments. The urban fabric has grown out of control in a claustrophobic way and incorporating the cultural heritage. All the recent construction is born in the last flat areas, while many coastal sites are located in inaccessible areas, where the height difference reaches even 45 meters high. A limit for contemporary buildings that have invaded the last flat spaces still free.

\section{"Meanwhile" Strategies. Think Global and Act Local}

The project area was deliberately bounded from Punta Epitaffio to the roman dock of Miseno, because a redevelopment project for the waterfront of Pozzuoli already exists designed by Eisenman Architects. The paper tries to avoid traditional vision of the masterplan. A "classic" masterplan could be a project based on the zooning or a project where the citizens are not involved in the urban transformation. The construction site could be an urban void for years, as the Ex Sofer of Pozzuoli today, the key-site for the Eisenman's project.

The strategy is to intervene in a surgical way reusing coastal and maritime archaeological sites, the only areas still empty and not affected by squatting. This approach is typical of the urban acupuncture, one big strategy with human-scale projects (Paquot 2014); urban transformations produced by several factors such as the economic crisis or the time gap that too often occurs between the approval of a plan and its realisation. Many of these projects are "pocket parks", green areas actively managed by citizens (Weaver 1969). The small-scale public green represents one of the most successful applications.

As Lerner explains, urban interventions should occur at strategic focal points, helping the normal processes of planning to work faster. Cities are rapidly growing and their problems are growing with them at the same pace. Planners nowadays do not have any time to plan cities constantly changing, in a slowly evolving manner. This alternative seeks the allocation of urban projects with high impact whose evolution progresses with the evolution of communities. This process called Urban Acupuncture. Urban Acupuncture takes the city as a living body, grasping the whole vein of the city in the process of urban regeneration and growth; it will activate its potential and promote the city's regeneration (Carter 2008). There is not a precise set of rules for the application of the theory of urban acupuncture, just principle ideas. Nevertheless, it is possible to draw up some general criteria as recommendations for the design. According to Manuel de Sola Morales, the location of the sensitive point is the first step in the urban acupuncture strategy 
(Solà-Morales 2004). The location is crucial in order to discover which critical point can activate potentials to get the maximum results. Looking for a strategic location to place the catalyst will be the first criterion. The second criterion would be to work together with the local residents; the most successful small public spaces are the ones that are responsive to the needs of their users. The third criterion is determined by the nature of the catalyst. The type of catalyst is determined by the purpose, programming, size, shape and the surrounding land use. It is important to find out what the users need and the catalyst should have a strong identity; the place should be important by itself.

The passage is represented from a big one entity, in a multitude of small elements, the transformation from a single-function zone to a mixed-use area (Rebois 2014). If one function is erased it could be substituted with another one, without modifying the others; a dynamic vision of the urban project. It is possible to adapt various uses in the areas, responding to various needs in a variable period. The time is the main problem. In Italy, projects are always very long time, often these urban transformation of vast areas are not completed. Fast transformations are urgent with low economical resources. An urban process will start with a low budget and thanks to initiatives of the local associations, very active in Phlegraean Fields. If we think in a traditional way, the citizens can enjoy an area with cultural activities only when the construction will be complete, after minimum 5 years. If funds end, the area will remain empty and unused, waiting for a transformation. The diagram of this approach is linear, does not allow alternatives and eventual modifications require expensive upgrades of the basic design. The dynamic approach attempts to avoid this situation through the plurality of choices, ensuring the fruition of the sites. 
Figure 8. Meanwhile Manifesto by P.Bellavita, A.Djordjevic, D. Lee, H.P. Pereira, L. Piazzi, M. Russo

\section{MASTER PLAN}

TODAY

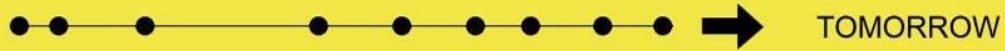

MEANWHILE MANIFESTO

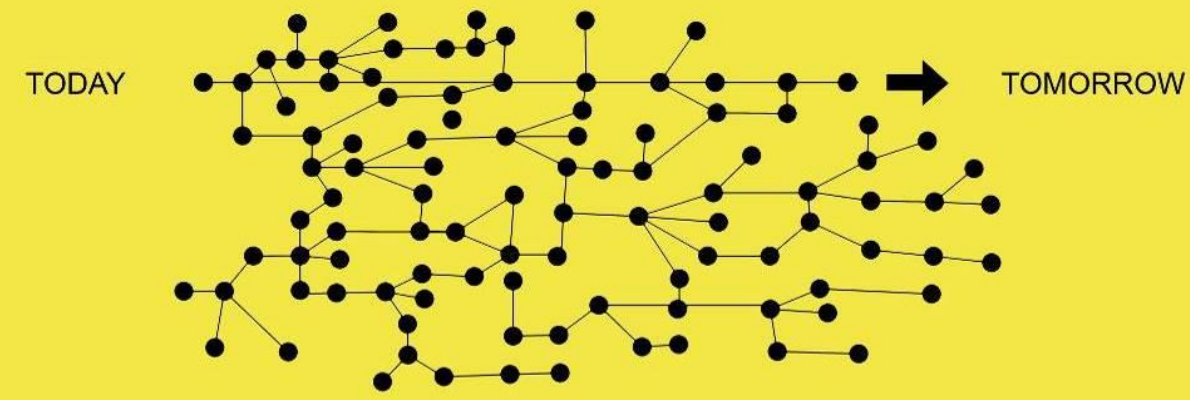

Source: Bellavita, Djordjevic, Lee, Pereira, Piazzi, Russo

The two diagrams below are only a graphic solution to allow the understanding of the differences between the two design approaches. The real diagram is the timeline, the only way to identify differences between the projects. In the first scheme, there is the process of the ordinary urban project: designing phases with architectural competition or not, approval of the project and construction of the project. The second scheme have a different management of the space because the citizens can change the project and choose activities to play in that space.

Multiple solutions can be generated with different results. Different results from different solutions generated by relations between public and private sector and citizens' associations. The "waiting period" becomes shorter, one or two years at most for the first urban actions. The archaeological remains are the most evident examples of a land waiting for a transformation. Taking up some concepts expressed by Alois Riegl on cultural heritage, the monuments are subjects who suffer from the deviations of the story (Dal Co 1990), sleeper subjects, completely abandoned and permanently altered. The project area is wide. Between Baia and Miseno there are $7.1 \mathrm{~km}$ of coastline plus $4.7 \mathrm{~km}$ of Pozzuoli coast. The most of the coast is dotted by residences; there are not public spaces for citizens. Archaeological sites may partly take care of this lack with a dual effect. The first effect is to regenerate archaeological areas currently abandoned. Second effect is to renew the identity of this area, restoring a dynamic relationship with the sea and opening connections from the coast penetrating the densely built area from Baia up to Miseno. Working with global strategies and local urban actions is the challenge. Working 
simultaneously with a large-scale and a small-scale to establish a network of connections and activate potentials (Shidan and Qian 2011).

\section{"Players"}

Who "play" to transform contemporary city?

Urban projects have reached a very high complexity, urban plans of the nineteenth-century matrix tools are dated, the scale is different and the subjects changed. The public was the only architect of urban transformation. Today multiple subjects, from private sector to non-profit organizations / start-up, can start urban interventions. Many urban transformations started by free citizens with a strong civic sense. In Phlegraean Fields, there are several associations for the protection and development of the archaeological assets, a sort of selforganization (Boonstra and Boelens 2011) for the promotion of the cultural heritage. It would be useful to establish an interface between citizens and institutions. A concept illustrated in an exemplary manner by Spanish designers Ecosistema Urbano in Masterplan for the city centre to Asuncion in Paraguay. The concept developed under the name of ASU-LAB (Tato and Vallejo 2010). It is a place where the public projects and the best ideas of the citizens come together and create a new synergy that ensures the development of a project that will fit perfectly into the urban system. In Italy, we have already these mechanisms, but there is not the urban infrastructure for these proposals. Another new factor is the ability to interact with private investors, in this place ideas can find a "sponsor" who invest in the ideas. The task of this laboratory is not only to select the best ideas. After the beginning of the urban process, it remains active allowing you to select and publicize the various activities hosted in the developed areas. The actors of this change in the urban project for Asunciòn can choose from 10 macro-functions that will mark the development of the area for a specified period. A very interesting idea and easily applicable even in the case of the Phlegraean Fields. Where no-profit organisation act without the institutions and citizen's needs are disconnected from public activities. A fundamental concept to design urban projects at different scales. The idea is that function does not require a physical site because generated from the combination of interests between the various actors of urban modification. It is an Office for the change.

\section{Phases of the Urban Vision}

The opening of coastal archaeological sites and a schedule of visits to the underwater heritage in accordance with citizen's organizations, which already perform these activities independently. It would represent the first phase (1-3 years) of the process, is a very important stage in order to bring people to the area and allow investors to discover the sites and their potential. The diagrams below are designed for the area of the Nymphaeum of Claudio and Pisoni's villa. 
Figure 9. Scheme and Timeline of the PHASE 1
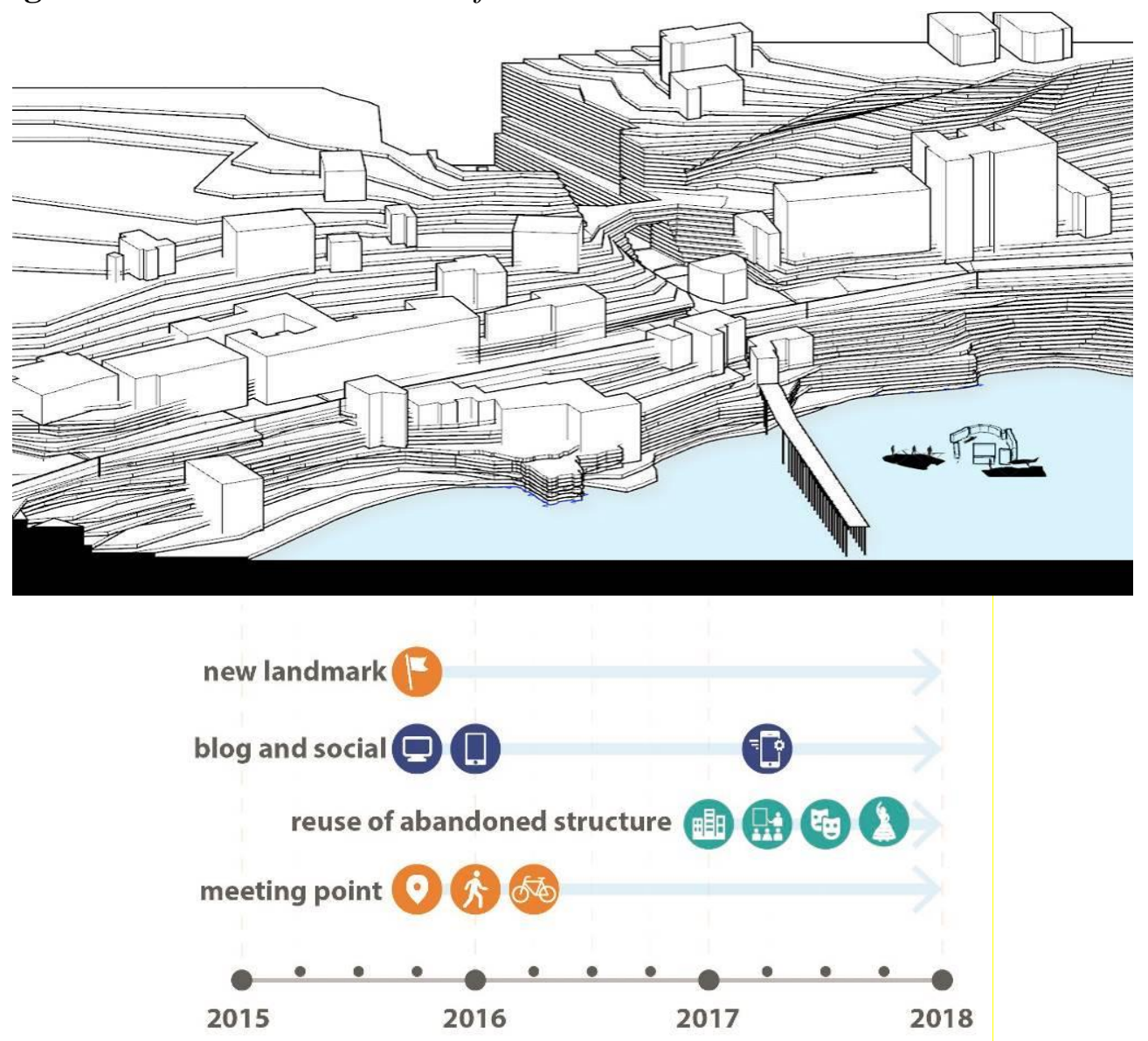

Source: M. Russo

The second phase (3-5 years) is represented by construction of structural elements to be placed on six sites previously identified. Contemporary Mirador have the main function to connect new public spaces, between land and sea, vertical and horizontal connections placed in the six strategic sites. 
Figure 10. Scheme and Timeline of the PHASE 2
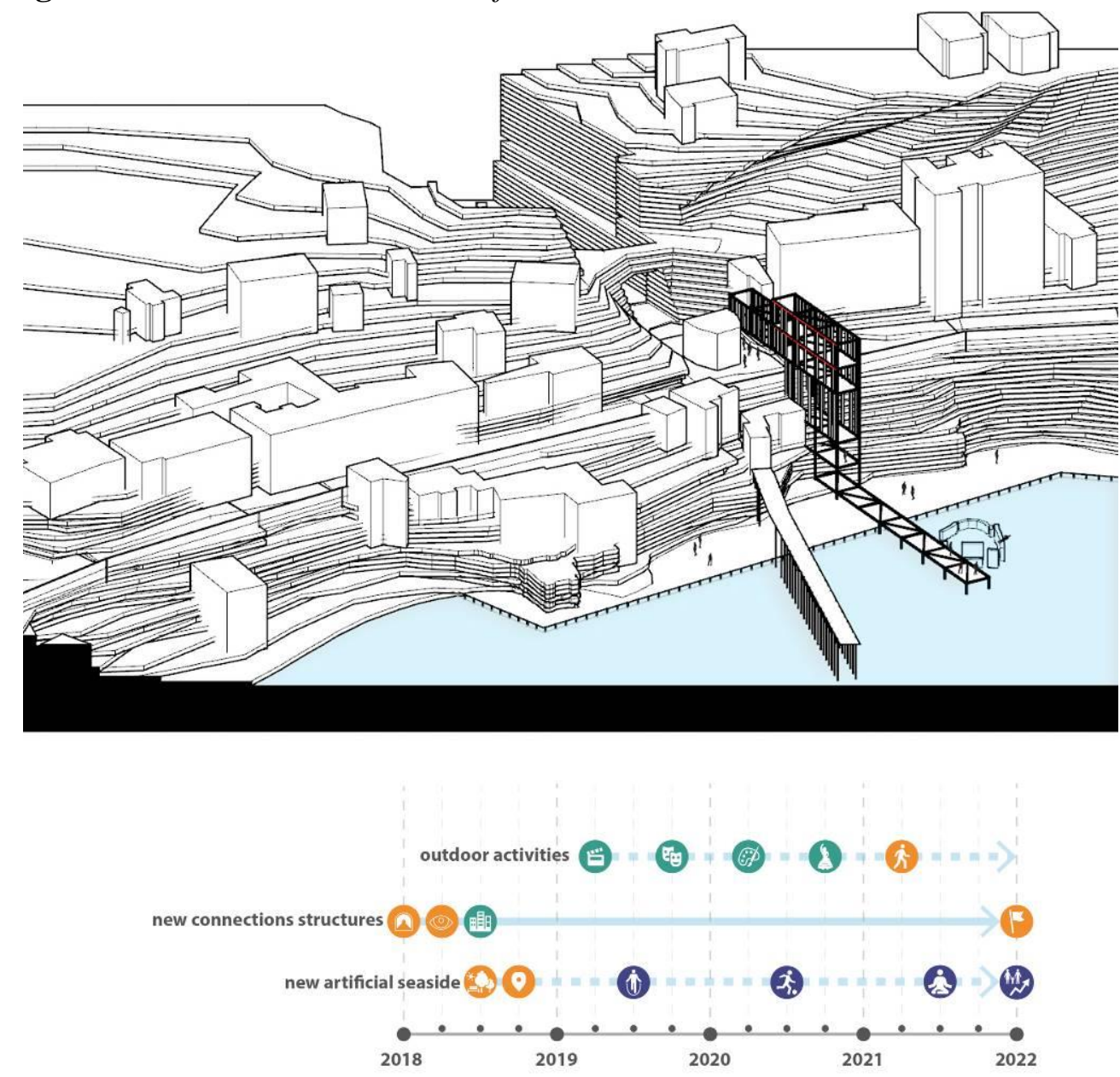

Source: M. Russo

The third phase (10-20 years) is represented by the development of the surrounding areas to the archaeological sites through the construction of public interest functions and great tourist attractions. Activities not present in the area as a centre of underwater archaeology, theatre or an auditorium or a business incubator. Also function as hotel, maybe in a territory that want to live with tourism would be one of the first options. If the function will not build, people could use the area with temporary activities. In the timeline of the figure 11 is clear the program of this urban vision. The space of a possible urban transformation used by citizens for temporary activities. In this schematic timetable, the citizens do not perceive the waiting period, since the first years the area used with temporary functions and dynamic activities. 
Figure 11. Scheme and Timeline of the PHASE 3
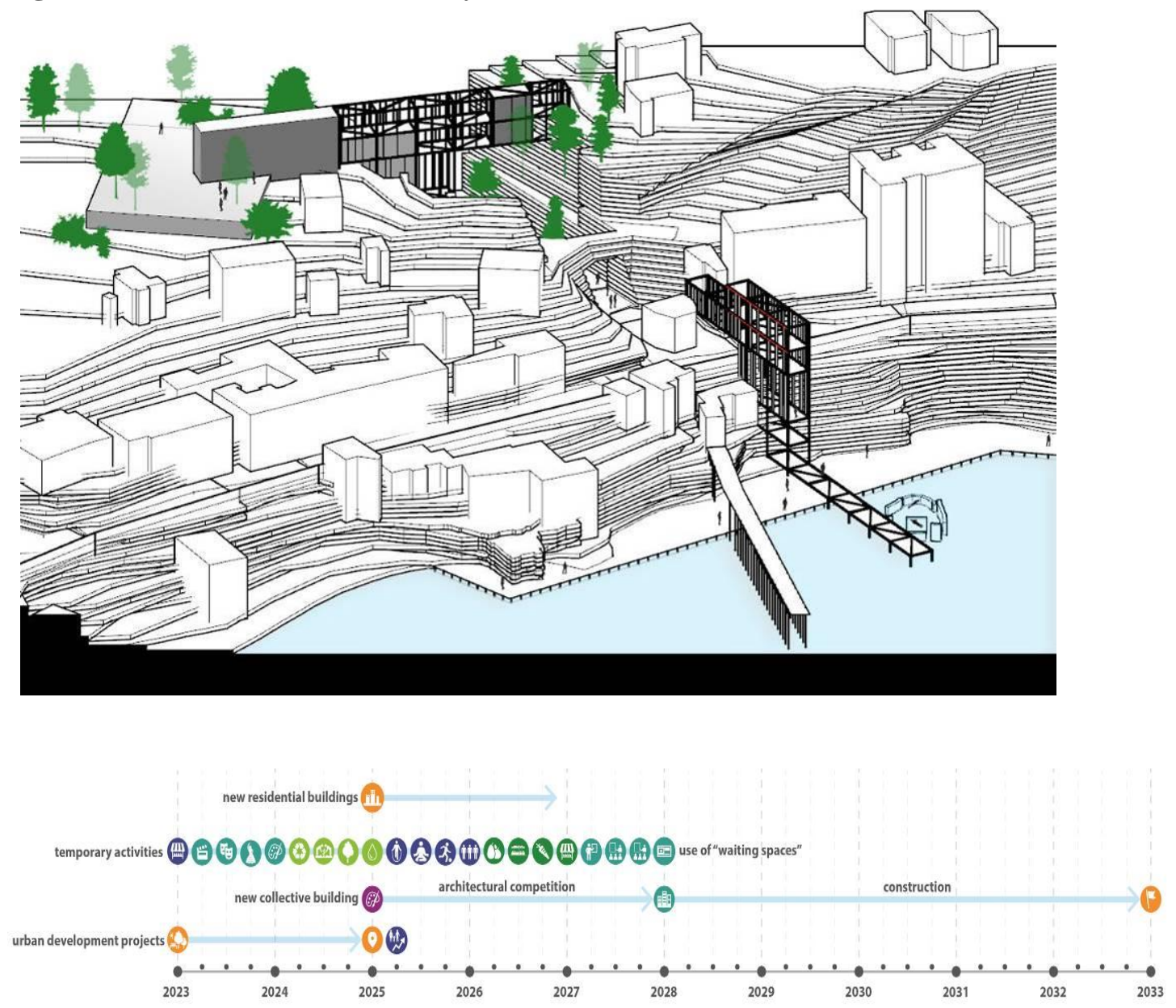

Source: M. Russo

\section{Strategic Archaeological Sites}

The project area from Baia to Miseno is long $7.1 \mathrm{~km}$; these areas are not included in the general masterplan for Pozzuoli designed by Peter Eisenman in 2009. The entire shoreline from Pozzuoli to Miseno is long 11.8 kilometres. In the roman period the site was connected by a coastal road called via Herculanea, now submerged due bradyseism. Along this submerged road, there are coastal and underwater archaeological cultural assets, the most important is the Aragonese Castle of Baia built on the ruins of a roman villa. All these buildings are monuments of I century BC. There are coastal theatres, maritime villas and monumental structures for fish farming. The modern city grew on fringes of the archaeological sites.

The roman road becomes again a virtual trace in the landscape as the Le Corbusier's Plan Obus (Picon 2015). Currently, all sites are urban voids, waiting for a development or a restoration project. The sites are suggestive, most of them located on high ground, natural podiums with an amazing point 
of view on the bay. The high altitude differences "protected" these areas from uncontrolled construction of '70. The submerged and coastal cultural assets undergo important and permanent modifications. In the port of Baia was built the shipyard over roman structures, see the figure 4 in this paper with the roman ruins $(\mathbf{g})$.

Figure 12. Plan of the Archaeological Sites with the New Urban Vision

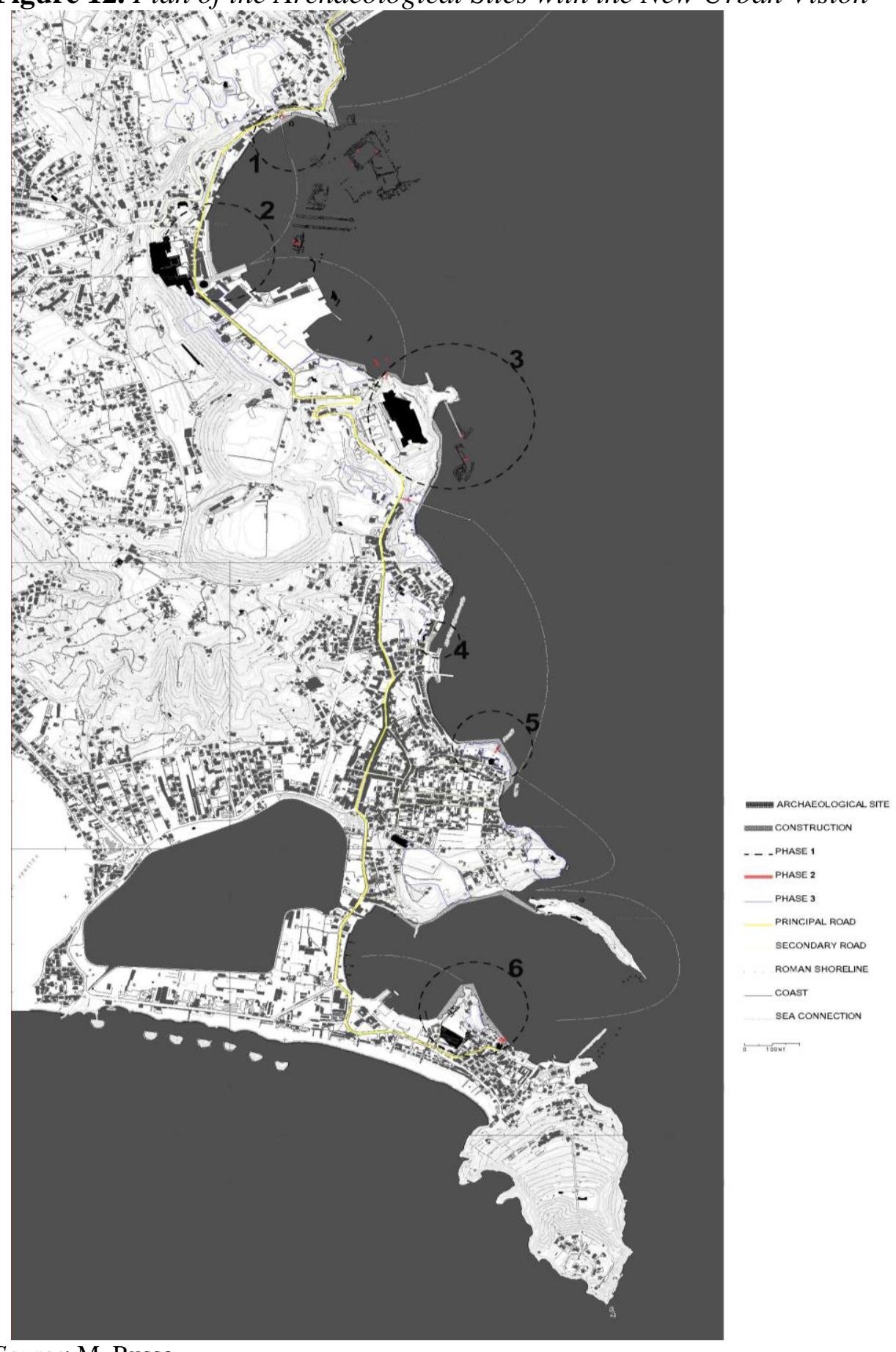

Source: M. Russo 
The location of this cultural heritage are strategic to start an urban development from the coastline to internal areas, an urban connection to enable citizens to live again the sea, like in roman age. Six strategic archaeological sites are selected for this urban vision.

\section{Nymphaeum of Claudio and Pisoni's Villa}

Two submerged sites characterize the first archaeological site. The nymphaeum of Claudio 70 meters far from the coast with a maximum depth of -5 metres. A small rectangular building with a structure that reproduce a natural cave with a vestibule where were located the statue of Ulysses, Baios and Polyphemus. Today preserved and partially reconstructed in the Museum of Phlegraean Fields. The villa of Pisoni was a residence belonged to a very powerful family in Roman times, who conspired against Nero. This act was the defeat of the rich family and marked the passage of the villa to Imperial public propriety. The building built in I century BC. It develops around a rectangular court $(95 \mathrm{~m} \times 65 \mathrm{~m})$. The pillars that surrounded the Court are still visible; today this is one of the leading sites for diving tours, given the relatively low sea bottom.

Figure 13. Proposal for the Site of Nymphaeum of Claudio

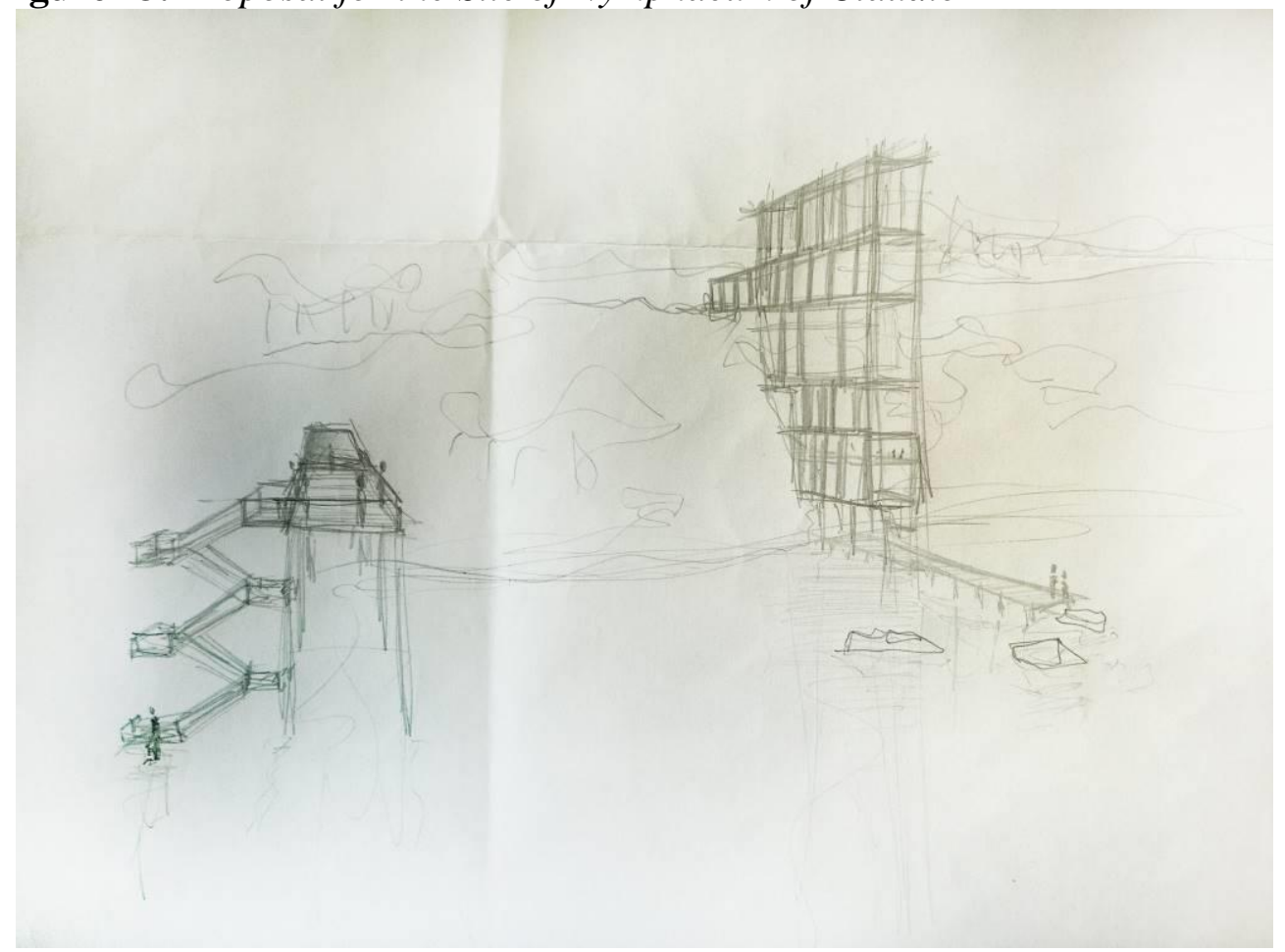

Source: M. Russo

\section{Baianus Lacus}

In Roman age there was a coastal lake called Baianus Lacus and quoted from Seneca, Tacito and Marziale, who disappeared due bradyseism, but recognizable by ancient remains on the banks. An artificial ship canal marked 
Vol. 2, No. 1 Russo: An Alternative Approach to the Conservation and Fruition...

the entrance to the lake, identified few years ago, that today is at $6 / 8 \mathrm{~m}$ underwater.

Figure 14. Proposal for the Port of Baia, before and after the Project
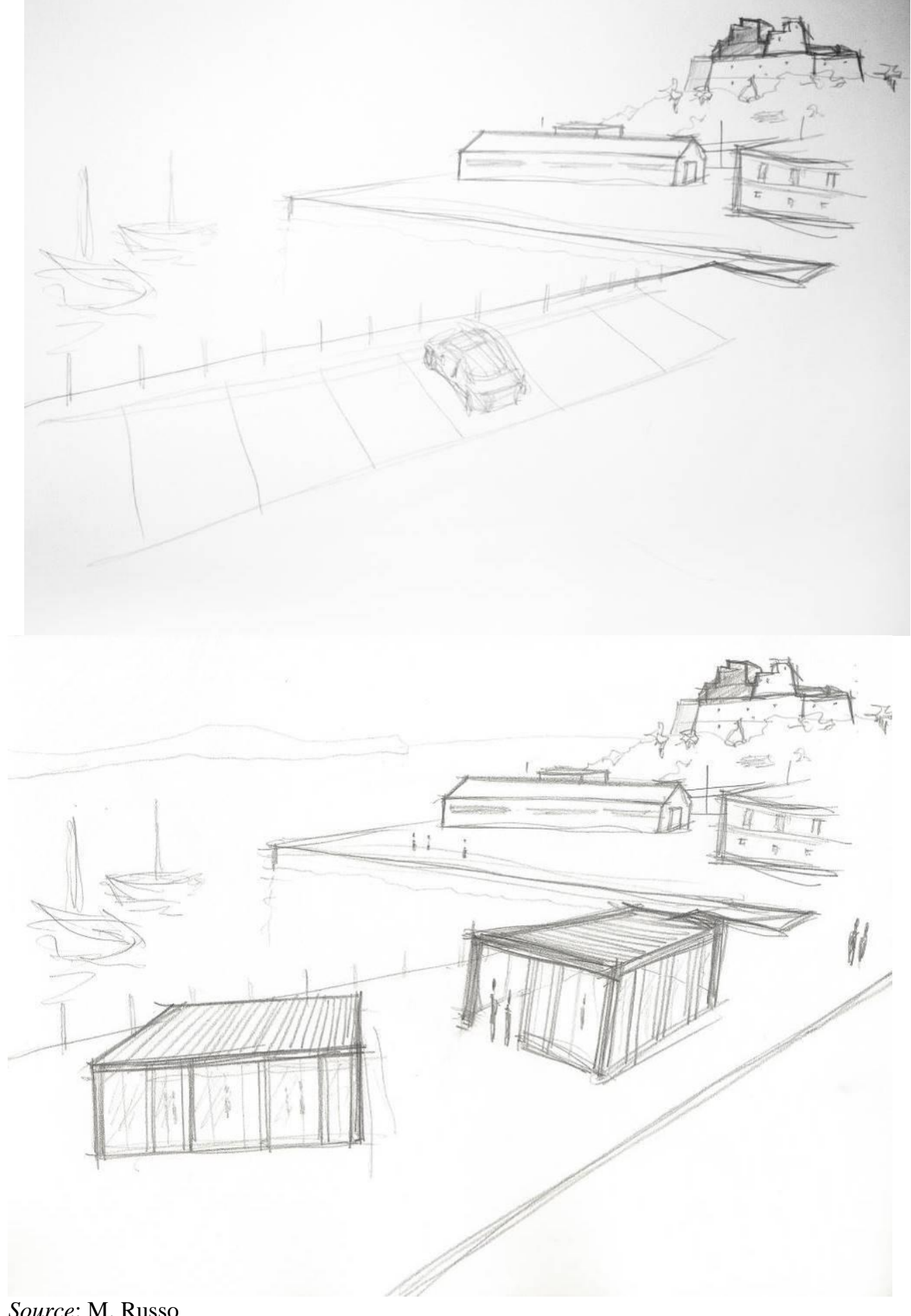

Source: M. Russo 


\section{Aragonese Castle of Baia and Stagnum Neronis}

The project area is under the Aragonese Castle of Baia, which is the Museum of the Phlegraean Fields, 4 meters underwater. It is an important roman fishpond of the I century BC, built on the ancient road called "Via Herculanea". This stretch of road is identified as an extreme offshoot of a seaside villa and shows an elaborate succession of ponds, porches and scenic pavilions occupying an area of approximately $300 \mathrm{~m} \times 80 \mathrm{~m}, 300 \mathrm{~m}$ represent 1.000 roman feet $(1$ roman feet $=29,65 \mathrm{~cm})$, a measure that in Baia not even billionaires could afford at the time. The monumental area and the great deal for the realization, there was the desire to impress at all costs; the palatium built over the stagnum was the residence of Nero (Miniero 2000), as shown by excavations recently conducted by Dr. Paola Miniero (Miniero 2010). The villa occupied the best position in the Phlegraean Field where it was possible observe all the volcanic territory. A monumental building that had a direct connection with the sea, yet the tunnels dug into the tuff partially destroyed during the construction of the Aragonese castle in 1493-1495. The area has an exceptional concentration of archaeological and geological resources in a restricted area (83.2 hectares). The pier not far from Aragonese Castle is strategic for the project. It should be a dock for boats. It is a disused element used to transport materials from the abandoned tuff quarry on the coast. An empty space that could become the access to the area. During transformation process, it will increase the area of the beach below the castle with the dual purpose of increasing public space and easily reach the site of Stagnum Neronis. The vertical connection is positioned in the most practical point, reusing part of the quarry and with the main road closer, which was not subject to recovery after the demise of the cave. The height of the rock face at this point is to 32.6 meters.

This area should be the most important for the presence of the Museum of Phlegraean Fields in the Aragonese Castle of Baia. Data from the museum are dramatically low. In the table below, there are number of visitors with the tickets sold. The first phase is focused on the outdoor areas of the Castle, the roof terrace and the entrance square, should be used for public activities. Periodically roof terrace could be used for public performances not managed by the museum staff. An ideal solution will be to organize weekly events as cinema discussions, book reviews, theatre performances and similar social activities. In the second phase is necessary a physical vertical connection with the realisation of an artificial shoreline as a link with the existing beach under the castle, a new public space under the rock face, in front of the underwater archaeological site of the Stagnum Neronis. This solution will guarantee visit tours during the entire day. The figure 15 shows a possible reuse of the existing quarry. Abandoned structure used to transport tuff from the cave behind the rock face of the castle to the ships. Today the cave site is highly degraded area and it could be used for the phase tree.

The function of a centre of underwater archaeology will be a very interesting solution to insert in this area due to the presence of the museum of Phlegraean Field, a research centre specific on this theme with other functions 
as a hotel and a restaurant with the help of private investors. One of the main best practices is the extension of the Viking Ship Museum of Roskilde in Denmark built in 1996, designed by the Danish architecture office Hou \& Partnere A/S. These functions improve the number of visitors and guarantee the possibility to organize temporary exhibitions on the researcher's work. In this way, the museum will have permanent (dated) exhibitions and periodical and original exhibitions.

Table 1. Visitors and Incomes of Italian Museum, Monuments and Archaeological Sites, $\boldsymbol{A}$ is the Tickets for Four Sites at 4 euro; $\boldsymbol{B}$ are only the Incomes of the Museum of Phlegraean Fields.

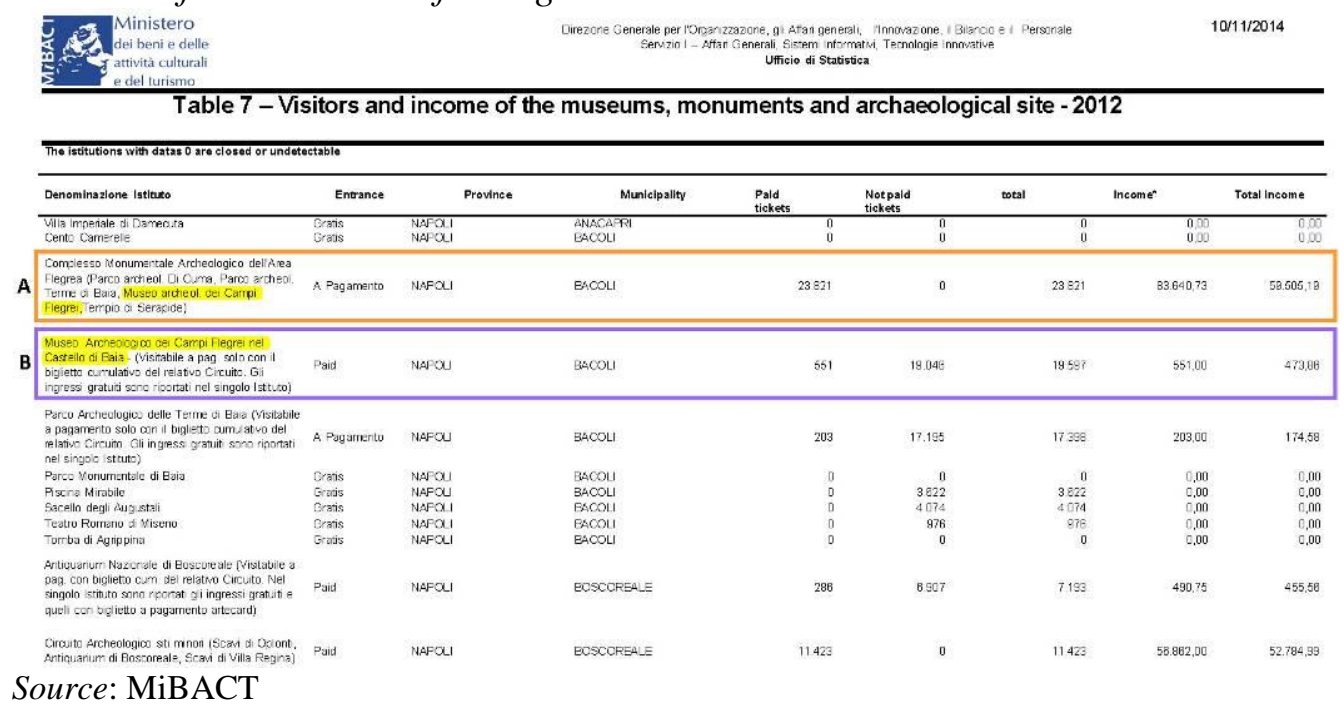

Figure 15. Vertical Connections for the Site under the Castle of Baia

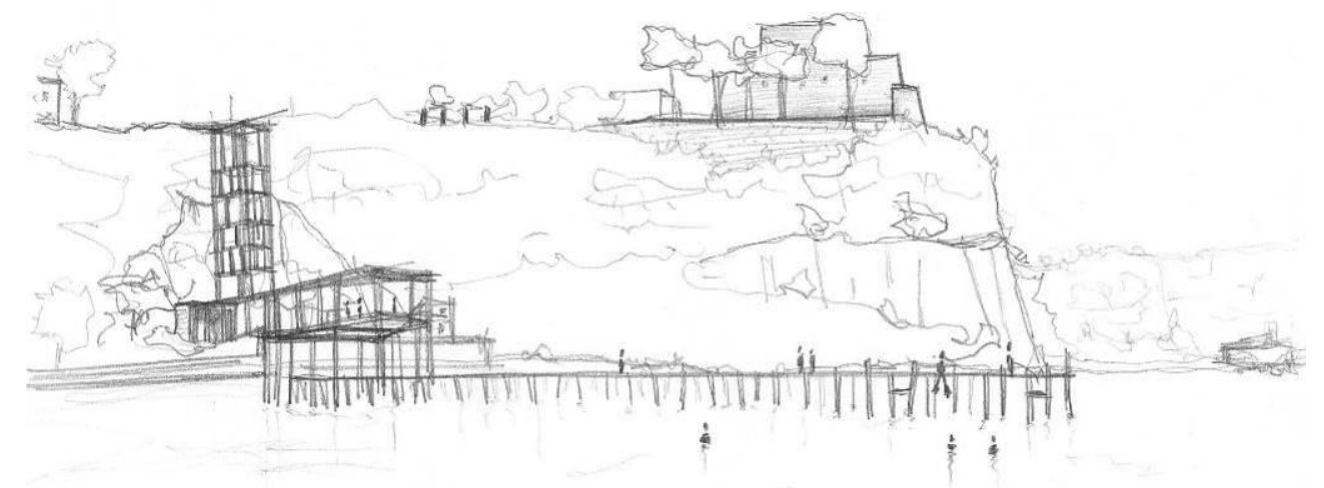

Source: M. Russo

\section{Maritime Odeon}

The monument is actually a theatre-nymphaeum, part of a destroyed impressive maritime villa. The structure was born as Odeon (indoor theatre for musical auditions or performances). The monument consists of three semi- 
cycles arranged on several levels: approximately at $1.30 \mathrm{~m}$ below the level of the current beach opens the first semi-cycle, while the median covered by rampant vault with on its extrados a staircase in opus reticulatum. Three openings separated by windows mark the outer wall. In the lowest side there is also a room covered by vault decorated with stucco. We can find similar decoration on the walls of niches, windows, and hallway that originally perhaps linked the building with the villa. On same level is located a third chamber, where the vault is collapsed and inner wall is marked by semicolumns covered in stucco with capitals of the Corinthian order, to form a kind of passageway divided into small compartments by transverse walls. The area is located at the same level of the sea but in recent development project, with the construction of a new quay, the site came not into this project and fell into a severe state of decay. In the first phase proposed project provide for reuse of the theatre with horizontal connection through the extension towards seaside. In the later stages is underlined an area with great potentiality, escaped to constructions of ' 70 . The area of 2,400 square meters. It is perfect for hosting collective and public functions, near principal driveway there is already a church.

\section{Nymphaeum and Centum Cellae}

The monument consists in a series of tanks, structure composed by two overlapping parts, completely independent, oriented differently and dating back to different ages. They were parts of a monumental villa, whose ruins are partly excavated in the tuff hill and fishponds partially submerged. The ambient excavated in the tuff, covered by opus caementicium and opus signinum. The presence of this type of hydraulic plaster and the curb at the base of the walls shows that these tunnels used as water tank. This area represents one of most critical points in the project because single-family residences invaded the area leaving free only the archaeological sites. Also for this topic is forecast a vertical connection from the archaeological heritage and the sea at 35 meters. One of the elements that would make possible to begin a process of urban transformation would be the construction of footbridges that would be both a dock and an artificial seaside. The archaeological area is only accessible from a secondary street; an additional access by sea would increase the catchment area of the site, by putting it in a guided tour along Phlegraean coast. An alternative to the vertical connection could be the construction of floating wood structures. A cheap and easy to construct solution, very useful for divers during underwater excavations.

This kind of solution will be unique in Italy. A didactic floating structure for the underwater archaeological sites to show people the work of archaeologist and conservators. There are not more examples of these solutions. One best practice was the Danish excavation for the Skuldelev Ships in 1962. The exact location was in the Roskilde Fjord, near the city of Kølhom. The excavation site became an attraction for 27,000 visitors in three months as Crumlin-Pedersen wrote in his books, a real successful tourist's attraction. 
Figure 16. Project on the Coast with Temporary Floating Structure

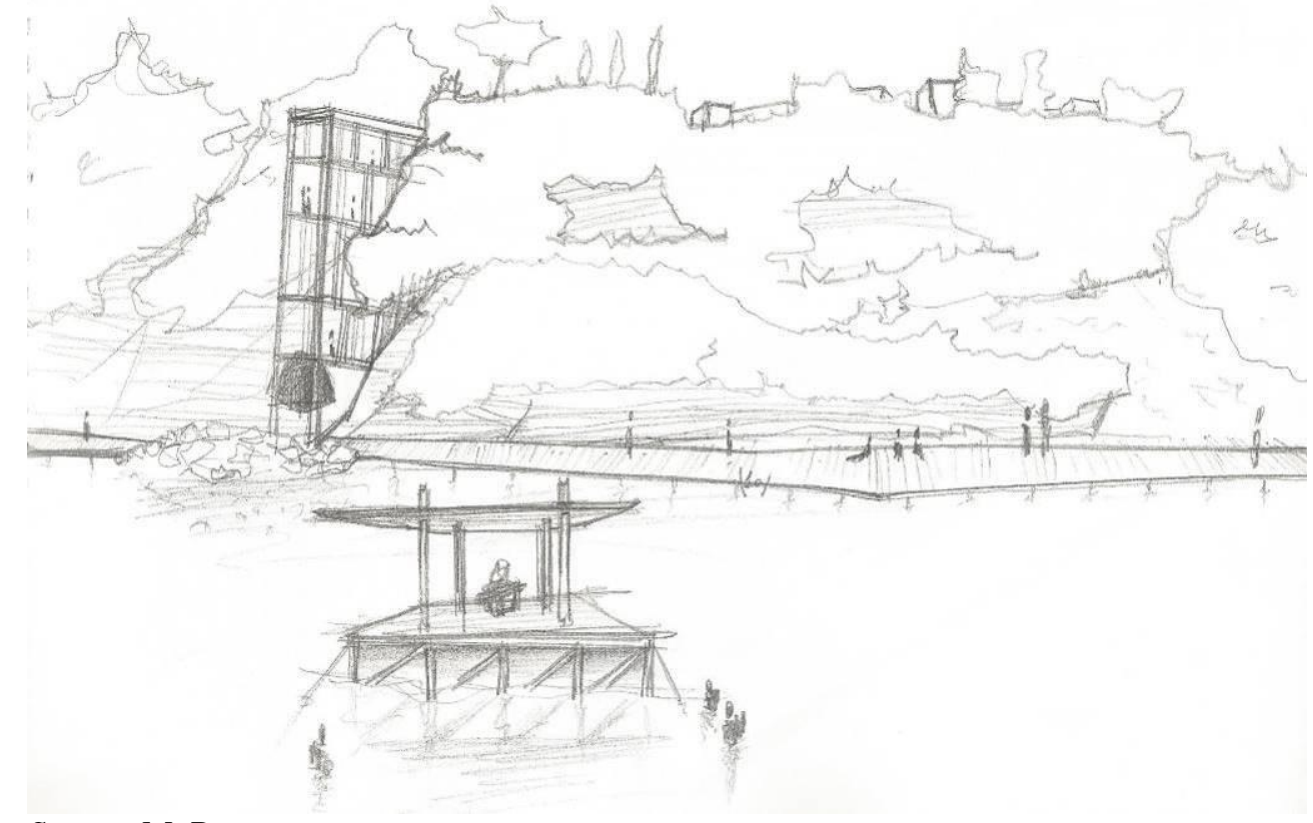

Source: M. Russo

Roman Theatre and Sacellum Augustales

Along the street "via del Faro" overlooks the best-preserved monument of ancient Misenum. This is a complex devoted to the cult of the Emperor Augustus, probably the "Templum Augusti quod est Augustalium" (The Temple of Augustus), mentioned in one of the inscriptions found during the excavation. There was supposed to be also the small hole of Misenum, with major public buildings. The temple, built in the existing forms during the II century BC, now is partly collapsed due to bradyseism. Behind the Sacellum Augustales there are the remains of the roman theatre, incorporated in a private building. There are only few galleries, pillars and part of the lower hallway. Interesting feature deductible from the plant of T. Rajola (1768) is a tunnel from the roman theatre directly to the dock on the street "via Herculea": this gallery currently ends in the sea. Recently there was a proposal for a tunnel 85 meters long to connect the two sites. 
Figure 17. Connection with the Island Pennata

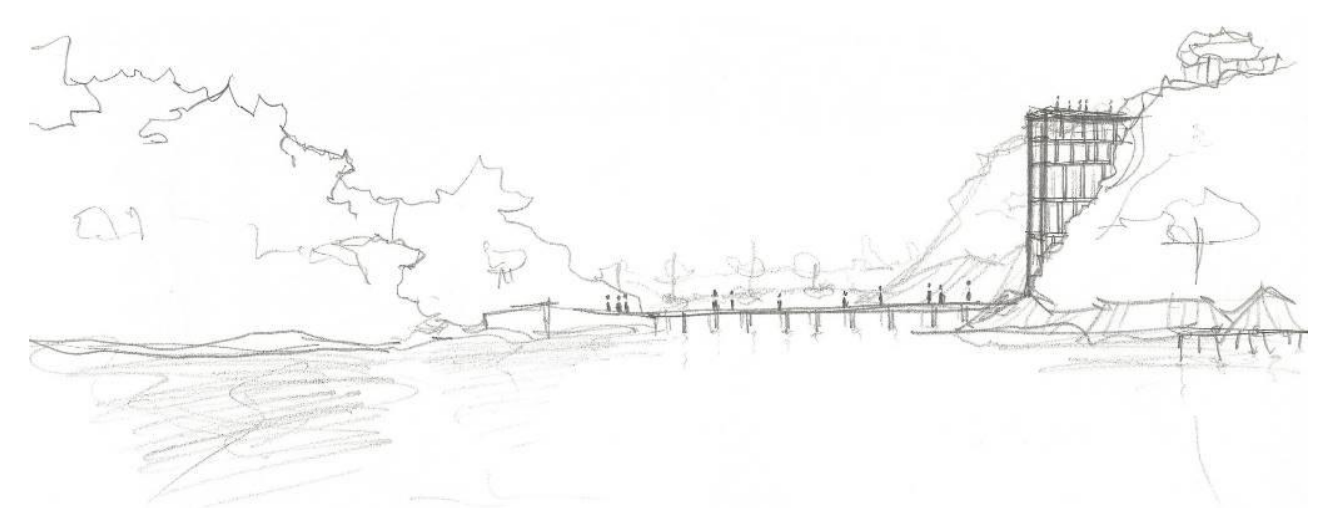

Source: M. Russo

The Roman Theatre of Miseno is an archaeological site with great historical importance. A recent excavation supposed that under the thick concrete slab there should be the forum of Miseno. Currently the area is blank and it might be interesting to start an excavation and convert the site into a didactic exhibition for visitors.

For the Sacellum Augustales instead it provided a simple and immediate intervention. Opening the site to visitors and use the area overlooking the landscape as vertical connection. This area is just 5 meters above sea level. Minimum intervention represented by a new plaza with an open side on the Phlegraean territory and other side to the archaeological rests, with a coastal link that would intercept the tunnel that connected the roman theatre with the sea (50 metres far) and the Roman walls to 300 metres away. A new artificial seaside at the service of citizens, which would guarantee a link to coastal sites. Creating a circuit with a better fruition of cultural heritage and providing citizens of a new public space that does not exist today. 
Figure 18. Study for a Floating Structure in the Site of the Roman Port

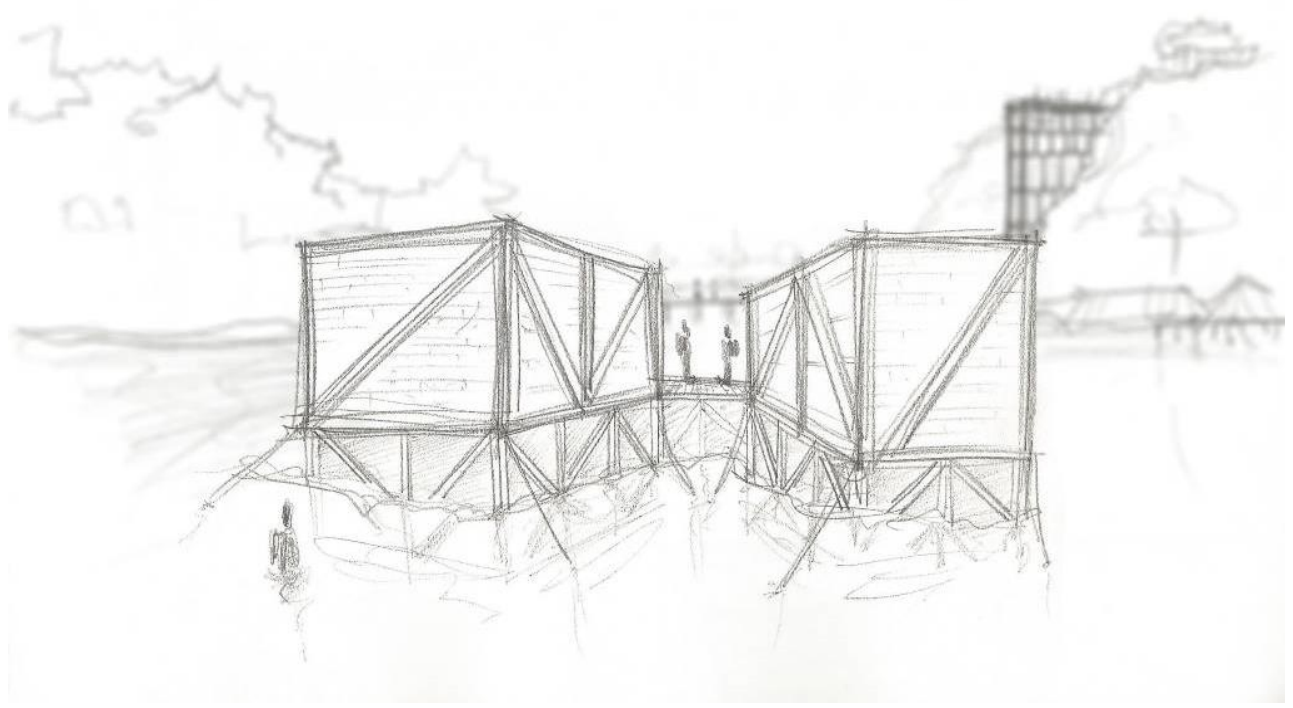

Source: M. Russo

The sketch (figure 20) shows a possible solution for the site, a plaza with a spectacular view on the landscape where will organize little events or exhibition of statues or parts of columns, which today is allocated on a crumbling wood platform in the site. Local associations, as the actor's organization "Misenum \& Marina Commedia", have already used the space for outdoor theatre performance during the Mirabilis Festival, a little outdoor exhibition as an open-air museum. One of the most important example of this kind of European museum of modern art is the Louisiana Museum in Denmark, where sculptures of Calder and Moore are exposed in an amazing landscape. It is a low budget operation; it should have been done with a simple wooden path. Otherwise for the exhibitions should been used the artefacts already present in the archaeological coastal site. During the phase two, it horizontal connection between this site and the water entrance of the roman theatre of Miseno will be built, so local people could have a new public space, an artificial beach and a connection between the two best preserved roman sites of the ancient Miseno. 
Figure 19. Plan of the Area, A_Theatre of Miseno, with the Possible Location of the Roman Forum; B_Sacellum Augustales

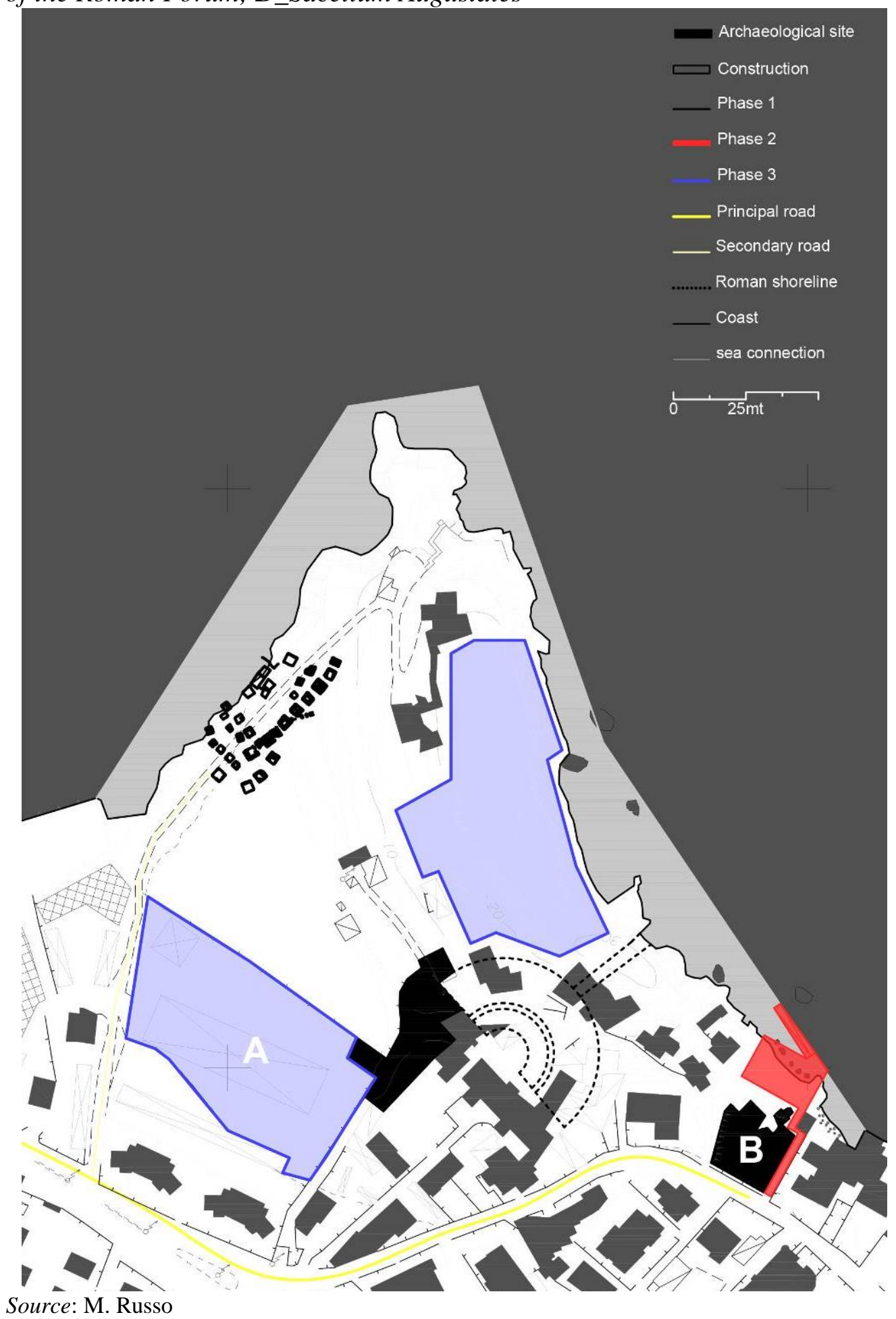


Vol. 2, No. 1 Russo: An Alternative Approach to the Conservation and Fruition...

Figure 20. Possible Solution for Sacellum Augustales, Phase One

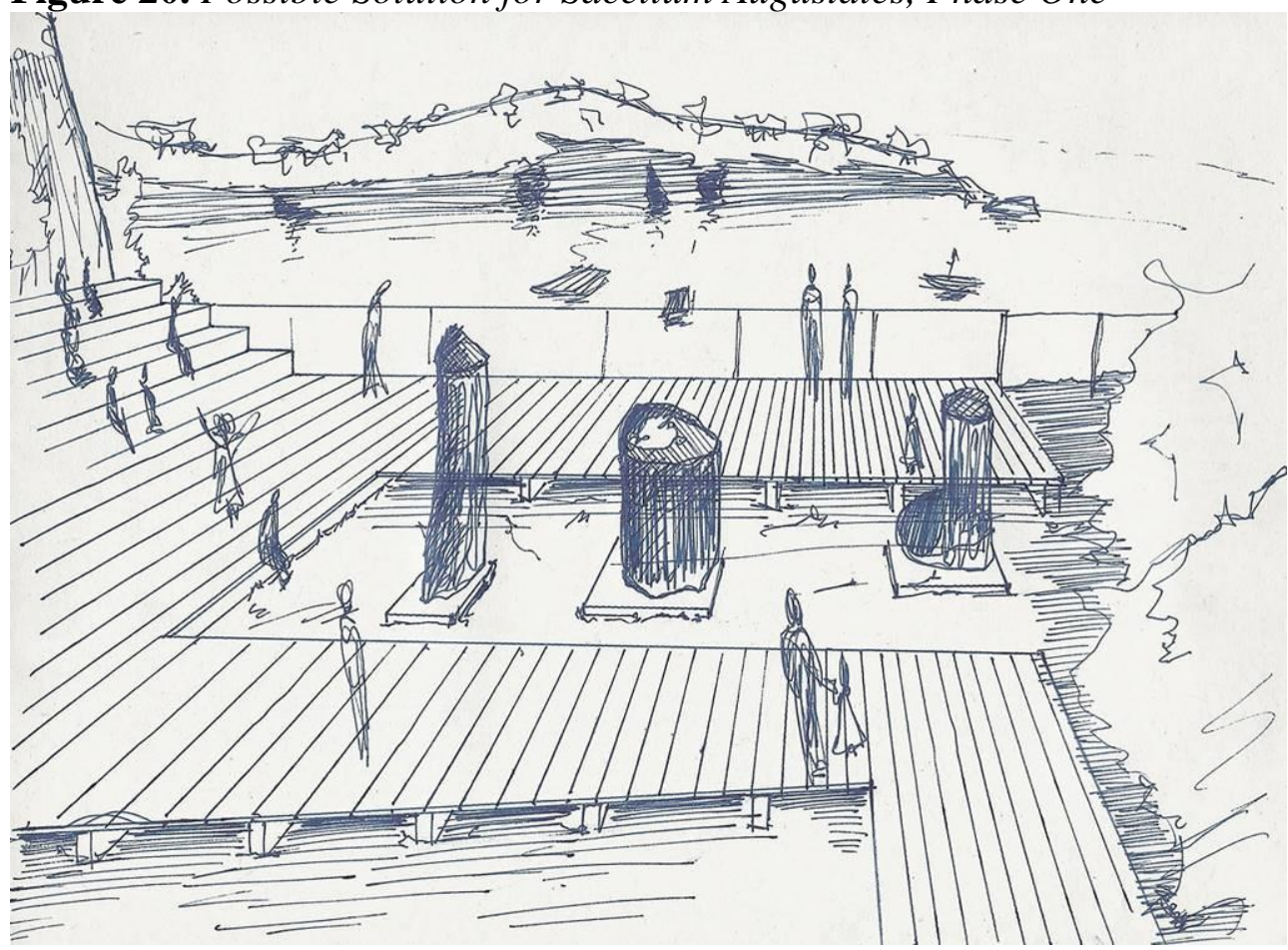

Source: M. Russo

Figure 21. Horizontal Connection between Sacellum and the Theatre of Miseno, Phase Two

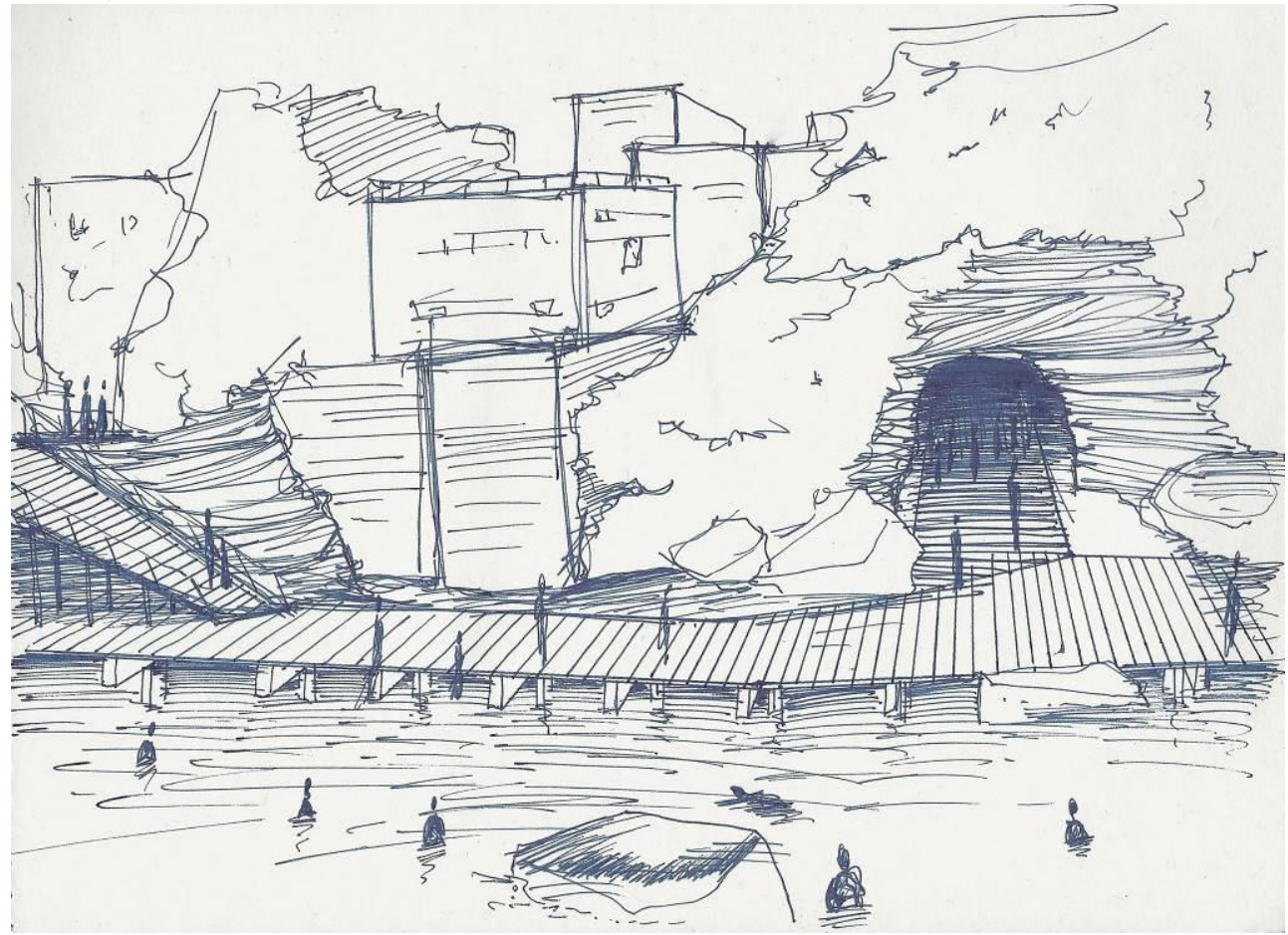

Source: M. Russo 
Figure 22. Possible Solution for the Theatre of Miseno, Phase Three

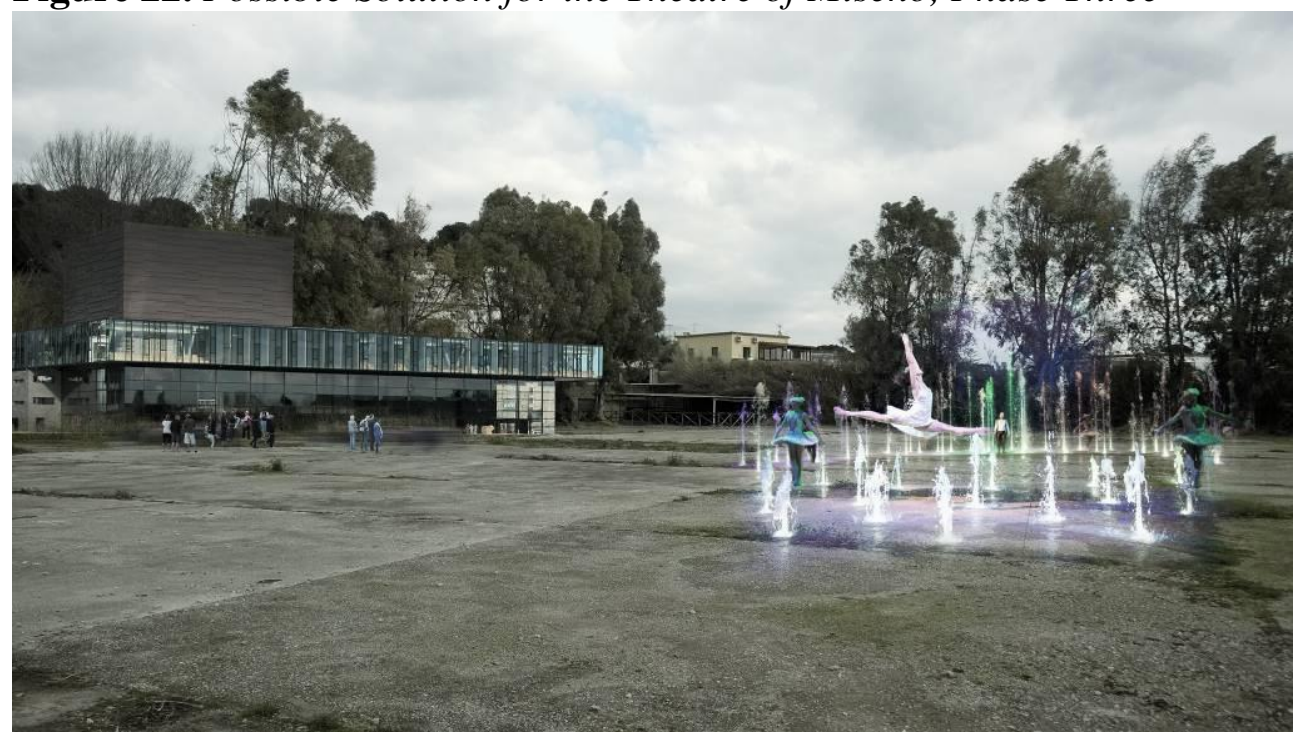

Source: M. Russo

\section{Conclusions}

The article tries to import an urban practices developed in Spain, where many architectural firms as Ecosistema Urbano or Paesaje Trasversal, are developing a series of projects based on temporary urban actions, respecting the identities of places and the citizens needs. In Italy, there has always been the goal of "eternal" projects. The economic crisis of recent years and the decline of contemporary Italian architecture require a change. One of these alternatives might be representing by this dynamic urban project; this study on Phlegraean Fields is a first test of how you might use these concepts. Interesting is the comparison with the Pozzuoli waterfront project. The criticism is not to the project, designed by one of the masters of contemporary architecture, but to dynamics and processes that seek to implement it, after several years of its approval is still at a standstill.

Is it a policy act to attract voters?

Meanwhile, degradation of these areas increases, visiting these territories we can perceive clearly all the past glorious of the Phlegraean Fields but have not a clear vision of the future. The paper identifies six abandoned coastal and underwater archaeological sites, very close to the coast and at a depth of -7 meters maximum. Working in these six strategic sites with the insertion of vertical and horizontal connections, which do not become protagonists of the territory connecting physically the city with new coastal public spaces. The Phlegraean Fields have horizontal development with several vertical elements represented by historical monuments such as the Aragonese Castle of Baia, these vertical connections do not become "seascrapers"; solution designed by Le Corbusier for the city of Montevideo in the 1929 (Comas 2015). These structures would be lightweight structure merged with the landscape containing 
different collective functions, the key-concept is the possible development thought these elements.

Figure 23. Study for the "Seascraper"

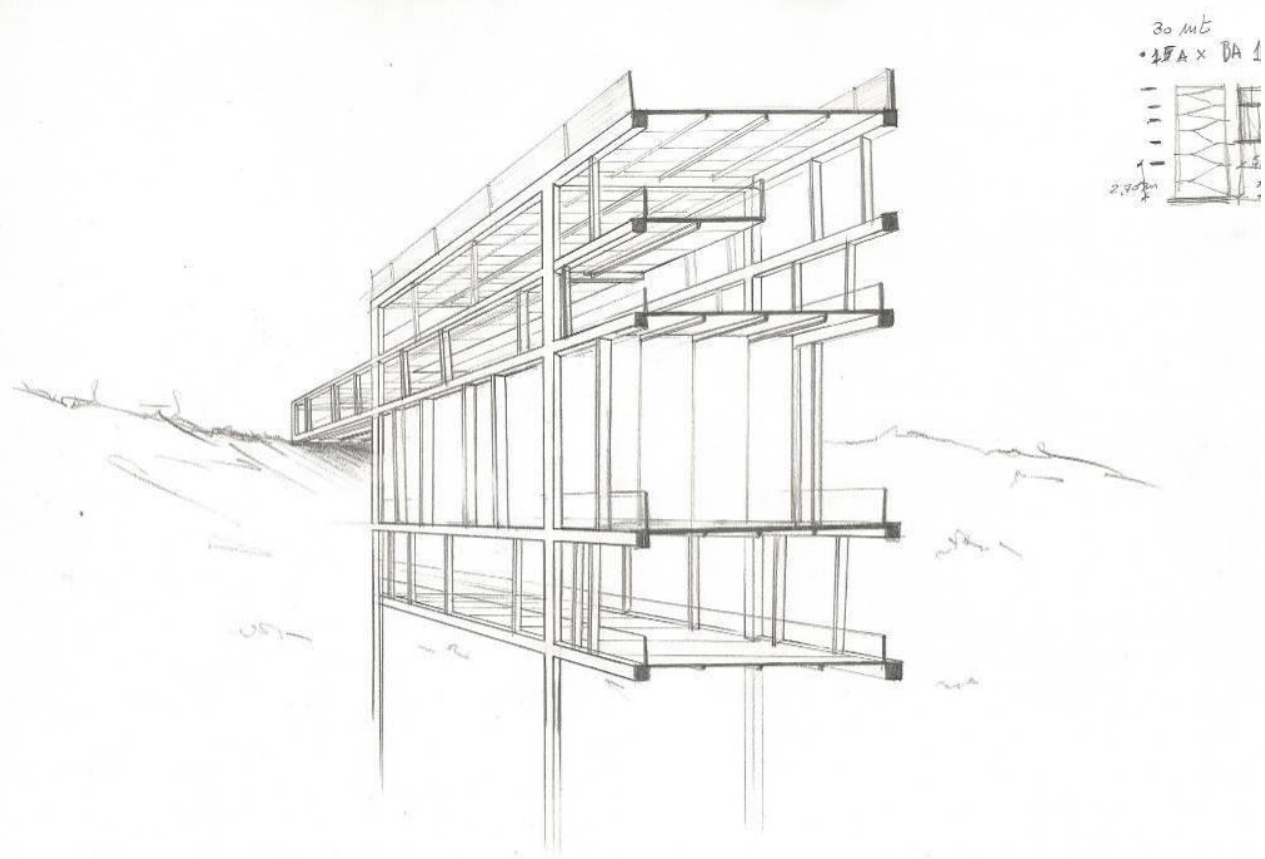

Source: M. Russo

These six sites are empty or disused areas where is possible to improve urban quality in the major residential neighbourhoods. The aim is to reconnect the internal areas with the sea, trying to eliminate the social difficulties related to the inability to enjoy the coastal areas, physically separated from the rest of the building. The municipality is working in a dated way, big urban transformations with high budget. The archaeological sites are not involved in these processes, the data about the museums visitors are the proof.

The urban vision explained in the paper is possible but only with collaboration of the municipality. The citizens are ready and waiting for this kind of urban transformation, a new way to develop this area, in a short period, starting from this amazing cultural heritage.

\section{References}

Boonstra B, Boelens L (2011) Self-organization in urban development: towards a new perspective on spatial planning. In Urban Research \& Practice 4: 99 122. DOI $=10.1080 / 17535069.2011 .579767$

Carter A (2008) Strategy and Partnership in Urban Regeneration. In P Roberts, H Sykes (Eds) Urban Regeneration A Handbook. London: Sage Publications Ltd. DOI= 10.4135/9781446219980 
Comas C E (2015) Brazil: Three Cities, Three Landscape. In AV Monographs 176 - Le Corbusier, An atlas of landscape. Madrid: Arquitectura Viva SL: 78-83

Carmona M, Tiesdell S, Heath T, Oc T (2010) Public places - urban spaces the dimensions of urban design. Oxford: Architectural Press: 133 - 137.

Dal Co F (1990) Figures of Architecture and Thought: German Architecture Culture, 1880-1920. Milano: Rizzoli.

Di Fraia G, Lombardo N, Scognamiglio E (1985-1986) Contributi alla topografia di Baia Sommersa [Contributions to the topography of submerged Baia]. In Puteoli, Napoli: 219-299.

De Solà-Morales M (1999) Designing cities. In Lotus Documents n.23. Milan: ELECTA.

De Solà-Morales M (2004) The strategy of urban acupuncture. In Structure Fabric and Topography Conference. Nanjing University.

Dromgoole S (2003) 2001 UNESCO Convention on the Protection of the Underwater Cultural Heritage. The International Journal of Marine and Coastal Law - Volume 18. Leiden: Brill: 59-108. DOI= 10.1163/ 157180803 X00025.

Fino L (2001) Vesuvio e Campi Flegrei. Due miti del Grand tour nella grafica di tre secoli [Vesuvio and the Phlegraean Fields. Two myths of the Grand Tour in three centuries]. Naples: Grimaldi \& Co.

Miniero P (2000) Il castello e l'area archeologica di Baia [The castle and the archaeological area of Baia]. Milano: Mondadori Electa.

Miniero P (2010) The Roman villa at the Castle of Baia: a re-examination of the context. In Mélanges de l'École française de Rome: antiquité: 2. Rome: École Française de Rome: 439-450. DOI= 10.1400/167154.

Maarleveld T, Guerin, U, Egger B (2013) Manual for Activities directed at Underwater Cultural Heritage - guidelines to the annex of the UNESCO 2001 Convention on Underwater Cultural Heritage. Paris: UNESCO.

Maiuri A (1983) I Campi Flegrei. Dal sepolcro di Virgilio all'Antro di Cuma [The Phlegraean Fields. From the grave of Virgil to the cave of Cuma]. Rome: ISPZ.

Paquot T (2014) Jan Gehl, one step after another. In L'Architecture d'Aujourd'hui 402. Montpellier: Archipresse \& Associés: 128-133.

Picon A (2015) Algiers: City, Infrastructure and Landscape. In AV Monographs 176 - Le Corbusier, An atlas of landscape. Madrid: Arquitectura Viva SL: 64 - 69.

Rebois D (2014) From mono-large enclaves to multi-mixed neighbourhoods or converting urban fortresses into porous fabric. In Europan 12 - The adaptable city. Paris: Europan Europe: 14-21.

Russo M (2014) Potenzialità degli spazi inutili: opportunità inesplorate per gli spazi interstiziali e aree dismesse [Potentiality of the useless spaces: unexplored opportunities for brownfield and in-between spaces]. In Agribusiness, Landscape \& Environment Management: An Interdisciplinary International Journal. Udine: Forum: 80-85. 
Scognamiglio E (1998) Aggiornamenti per la topografia di Baia sommersa [Updates to the topography of submerged Baia]. In Forma Maris, Forum internazionale di archeologia subacquea, Pozzuoli, 1998. Napoli: Massa: 43 -50 .

Scognamiglio E (2006). Baia sommersa. Alcune considerazioni sulla carta del Lamboglia (1959-1960) [Submerged Baia. Some considerations about the Lamboglia's document]. Archaeologia maritima mediterranea: International Journal on Underwater Archaeology 3. Pisa, Istituti Editoriali e Poligrafici Internazionali: 1-7. DOI= 10.1400/60989.

Shidan C, Qian S (2011) "Urban Acupuncture" Strategy in the Urban Renewal. In Electric Technology and Civil Engineering (ICETCE), 2011 International Conference on. Wuhan, Wuhan University: 1859 - 1862. DOI $=10.1109 /$ ICETCE.2011.5774234

Tato B, Vallejo J L (Ecosistema Urbano) (2010) Plan maestro para el Centro Histórico de Asunción [Masterplan for the historical centre of Asunción]. Pasajes Arquitectura 135, 30-37. Madrid: SGEL.

Urhahn G (2011) The spontaneous city. Amsterdam: BIS Publishers.

Weaver R (1969) Recreation needs in urban areas. In W N Seymour (Ed) Small urban spaces; the philosophy, design, sociology and politics of estpocket parks and other small urban open spaces. New York: New York University Press. 